IRON CONTENT OF FOOD COOKED IN IRON UTENSILS

by

CHERYL EILEEN NOSSAMAN, B.S. in H.E.

A THESIS

IN

FOOD AND NUTRITION

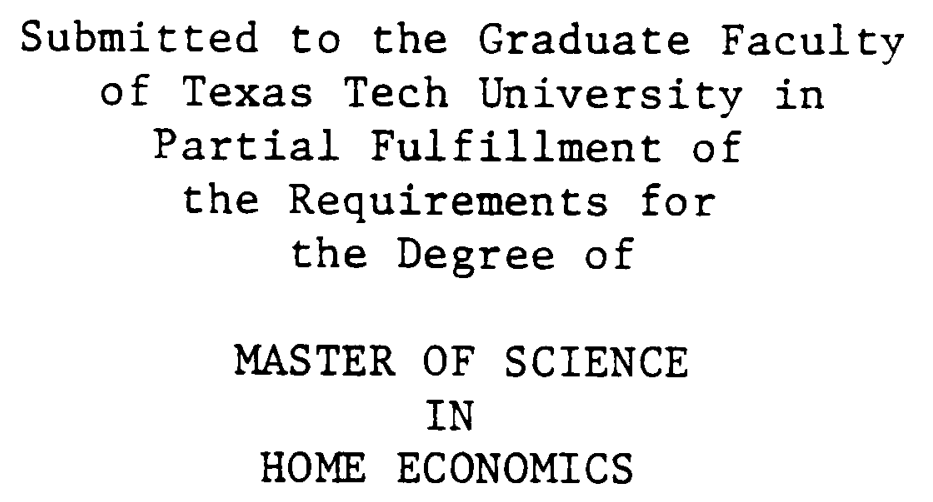

Approved

Accepted

May, 1984 


$$
\begin{aligned}
& 190 . \\
& \therefore \therefore 25 \\
& \text { acopo }
\end{aligned}
$$

\section{ACKNOWLEDGMENTS}

I would like to express appreciation to Dr. Helen C. Brittin for her generous guidance and direction of this thesis. I would also like to thank the other members of my committee, Dr. Barbara J. Stoecker and Dr. Merrilyn N. Cummings, for their helpful criticism. 
CONTENTS

ACKNOWLEDGMENTS . . . . . . . . . . . . . . . . . . . . ii

LIST OF TABLES . . . . . . . . . . . . . . . . . . . . iv

I. INTRODUCTION . . . . . . . . . . . . . . . . . . . 1

Purpose and Scope of the Thesis............ 1

Review of Previous Research ............. 3

II. METHODS AND MATERIALS . . . . . . . . . . . . . . . 9

Use of Iron Utensils Survey . . . . . . . . . . . 9

Iron in Food Study . . . . . . . . . . . . . 11

Statistical Methods............... 14

III. RESULTS AND DISCUSSION . . . . . . . . . . . . . 15

Use of Iron Utensils Survey . . . . . . . . . . 15

Iron in Food Study . . . . . . . . . . . . . 42

IV. SUMMARY AND CONCLUSIONS . . . . . . . . . . . . . . 56

REFERENCES . . . . . . . . . . . . . . . . . . 59

APPENDIX . . . . . . . . . . . . . . . . . . . 61 


\section{LIST OF TABLES}

1. Test for Independence for Fair and Convention Samples and

Discrete Variables in the Use of Iron Utensils Survey . . . . 16

2. Least Squares Means for Continuous Socioeconomic Data for

Fair and Convention Samples . . . . . . . . . . . 27

3. Distribution and Percent of the Convention Sample by

State. . . . . . . . . . . . . . . . 28

4. Test for Independence for the Use of Iron Cookware and for Discrete Variables . . . . . . . . . . . . . 29

5. Test for Independence for Use of Iron Cookware and the Number of Iron Utensils Owned . . . . . . . . . . . 38

6. Least Squares Means for Continuous Socioeconomic Data and the Use of Iron Cookware . . . . . . . . . . . . . 39

7. Least Squares Analysis of Variance for the Effect of Food, Treatment, Replication and Sample on Moisture and Iron Content . . . . . . . . . . . . . . . . . . 43

8. Mean Moisture and Iron Content of Food by Treatment . . . . 44

9. Means for Moisture and Iron Content of 20 Foods by Treatment . . . . . . . . . . . . . . . . 45

10. Means for $\mathrm{pH}$, Cooking Time and Moisture Content of 20 Foods . . . . . . . . . . . . . . . . . . . . . .

11. Least Squares Analysis of Variance for the Effect of Food, Treatment, Replication and Sample on the Moisture and Iron Content of Three Foods Cooked in Two Iron Utensils . . . . . . . . . . . . . . . . . . .

12. Mean Moisture and Iron Content of Three Foods by Treatment . . . . . . . . . . . . . . . 53

13. Mean Iron Content of Three Foods Cooked in Two Iron Utensils 
CHAPTER I

INTRODUCTION

\section{Purpose and Scope of the Thesis}

Iron is a mineral which is essential to higher forms of life because its central role in the heme molecule permits oxygen and electron transport (Beutler, 1980). It is highly uncommon for a nutrient to be found deficient in the peoples of both developed and developing countries. Iron is such a nutrient (Monsen and Balintfy, 1982). The iron content of typical diets adequate in other respects is estimated to be $6 \mathrm{mg}$ per $1000 \mathrm{kcal}$, but the amount of absorbed iron varies (Robinson and Lawler, 1982). Most iron, upon digestion, enters either a pool of heme iron or a pool of nonheme iron. Humans absorb heme iron, found as $40 \%$ of total iron in meat, fish and poultry, as an intact iron porphyrin complex at a relatively high rate. Nonheme iron, inorganic iron salts or all of the iron in grains and vegetables and approximately three-fifths of the iron in meat, fish and poultry, is absorbed at a lower rate (Monsen and Balintfy, 1982). Women, adolescents, infants and children are at risk of developing irondeficiency anemia. Women lose iron through menstrual blood loss or pregnancy. Infants and children need iron for increasing blood volume for growth. Both groups may not absorb all of the iron that they need from the typical diet. However, an increase in physiological needs will increase the rate of iron absorption (Beutler, 1980). Monsen and Balintfy (1982) summarized methods to improve absorption 
of nonheme iron through dietary modifications. The use of iron cooking utensils is a possible means to increase the amount of dietary iron. Studies by Bothwell et al. (1964) of the South African Bantus and Lal et al. (1973) have indicated that iron in foods from iron cooking utensils can be bioavailable to the organism.

There is little research available on the iron content of foods cooked in iron utensils. Some conflict in the literature as to the actual increase of iron in foods cooked in iron utensils is apparent. Generally, iron content of food has been shown to increase when cooked in iron utensils. Also, age and condition of the iron utensils may affect increase in iron of food cooked in iron utensils (White, 1968; Burroughs and Chan, 1972).

Moore (1965) and Mertz (1980) hypothesized that the decreasing use of iron cookware would have an adverse effect on dietary iron intake. White (1968) conducted a survey to obtain information on the current use and changes in use of iron utensils.

The focus of the current study is on the iron content of food cooked in iron utensils, as well as the factors affecting the increase in iron content of the food.

If $(0)$ Objectives of the current study were to determine the extent to which iron cooking utensils are used currently and to determine the iron content of a variety of foods cooked in iron cooking utensils and in non-iron utensils using household cooking methods. The effects of acidity, cooking time and moisture content of food and of different iron utensils on the iron content of the food cooked in iron utensils were examined. 


\section{Review of Previous Research}

Iron content of food cooked in iron utensils was studied as early as 1945 by Mackay et al. (1945). A study on the presence of anemia in wartime day nursery children was conducted. One part of the study was to cook three foods in three different types of pans (aluminum, iron and ename1). Mackay et al. (1945) found a fifteen-fold increase in the apples cooked in a polished iron saucepan in one nursery and a five-fold increase in the iron content of apples cooked in an oldfashioned heavy black iron saucepan in another nursery. Two other foods, stock and potatoes, showed no significant increase in iron content. The authors attributed the increase in iron of the apples to the acidity and longer cooking in time.

Under extreme conditions, cooking in iron utensils can lead to iron overload. This is seen in the high incidence of hemosiderosis, tissue deposition of iron without tissue damage, in Bantu subjects in South Africa. Bothwell et al. (1964) found that the majority of the subjects were taking in between 50 and $100 \mathrm{mg}$ of iron daily, most of which was present in their homemade beer brewed in iron pots. For comparison, the highest recommended dietary allowance for iron in the United States is $18 \mathrm{mg}$ for adult women, aged 23-50 (Food and Nutrition Board, 1980). Bothwell et al. (1964) have investigated the theory that the Bantus have increased iron absorption. It was found that the Bantus actually had lowered absorption compared to white volunteer subjects, particularly at the $25 \mathrm{mg}$ level of iron present in the homebrewed beer. The Bantus had a lowered absorption of iron due to the 
existing overload. Bothwell et al. (1964) also concluded that the degree of siderosis present in the Bantus could be explained by their high intake of iron alone.

Moore (1965) reported a large difference in the calculated iron content compared to the analyzed iron content of food cooked in iron utensils of foods served to the military of several countries, in contrast to usually close agreement between these values in the United States. The estimates of iron intake made from food composition tables ignore the contribution made from cooking utensils (Moore, 1965). Moore (1965) then investigated the effect of cooking in iron utensils. Seven foods were studied. The most acidic foods with the longest cooking times, spaghetti sauce and apple butter, showed the greatest increases in iron content. The greatest increase in iron found was approximately one hundred-fold, with apple butter cooked for 2 hours. But even the average five-fold increase of the iron in foods such as gravy, fried potatoes, rice casserole, beef hash, or scrambled eggs must be considered nutritionally important (Mertz, 1980).

As part of a study of iron status of menstruating women, Monsen et al. (1967) conducted an experiment to determine the possible effect of cooking with iron utensils on the iron content of the diet. Two foods, eggs and hamburger, were cooked in three well tempered iron pans and one aluminum pan. When iron content of the uncooked food was compared to the foods cooked in the iron pans, there was no increase in iron content.

In a study performed by White (1969), 24-hour diets of girls and 
young women were analyzed for iron content. The analyzed iron values were less than the calculated values for forty-one of the forty-eight composites. Two of the diets that had a higher analyzed iron content contained foods that were prepared in iron cooking utensils. Spaghetti sauce prepared in an iron utensil had $54.4 \mathrm{mg}$ iron by analysis and $7.4 \mathrm{mg}$ by calculation. Spanish rice in the second diet cooked in an iron utensil contained $13.8 \mathrm{mg}$ of iron by analysis and $11.4 \mathrm{mg}$ iron by calculation.

Results of a comparative study of the iron content of 18 Mexican-American foods were reported by Burroughs and Chan (1972). The iron contents of the foods were calculated from food tables and compared to the iron contents of these foods analyzed after cooking in glass or aluminum containers and in iron utensils. The largest percent differences were shown in chicken with zucchini, $356.3 \%$, and macaroni-beef stew, 238.7\%. Generally, it was found that the foods cooked in an iron utensil showed higher iron content compared to the foods cooked in glass or aluminum utensils. Overall, the foods cooked in iron, glass or aluminum had quite different iron values than the values calculated from the food tables.

Lal et al. (1973) fed four healthy adults milk boiled in cast-iron Karahi. They showed an increase of twenty percent in their serum iron within half an hour and the level was maintained up to 2 hours. The value at 5 hours was still raised by $10 \%$ of fasting initial value. Lal et al. (1973) found that boiling milk in a cast-iron Karahi resulted in a 30\% increase in iron content and fried potatoes showed an increase 
of $83 \%$ when cooked in cast-iron Karahi. The increase was significant at the 0.001 level.

In New Guinea, Drover and Maddocks (1975) conducted research using iron utensils to prepare native foods. Iron analysis of duplicate samples showed an increase in iron content of brown rice and green leafy vegetables, pumpkin tops, ficus leaves and Chinese cabbage. Indigenous foods such as cassava, sweet potato, seafoods, banana, pawpaw and pineapple did not increase in iron substantially.

A study by Seiler et al. (1977) in Germany, was conducted on the mineral content of beef, veal and pork, depending on the method of preparation. They found that cooking in an iron pan, especially frying, increased the iron content. They concluded that the increase was not nutritionally important.

Moore (1965) has suggested that the gradual substitution of aluminum and stainless steel for iron in the manufacture of cooking utensils may have a most unfortunate effect on dietary iron intake. White (1968) conducted a survey to obtain information on the current use and changes in use of iron cookware. Four hundred and thirtythree subjects were surveyed by questionnaire. The findings suggested that the use of iron utensils had declined and would continued to decline.

During the 1960's, atomic absorption spectrometry gradually developed into a powerful tool of "modern" trace element research. Atomic absorption spectrometry, originally developed in Australia, became available to the researcher. Used in the flame method or in the more sophisticated flameless modification, it greatly extended 
the detection limits for many trace elements (Mertz, 1980).

During the 1970 's, nutritional research on minerals and trace elements substantially intensified and accelerated. One of the main results of this research is that mineral and trace element interactions are now more completely understood and are recognized as important determinants of metabolism and nutritional status (Mertz, 1980).

The important interaction among iron, ascorbic acid and meat have been described and quantified, and recommendations for application were outlined by Monsen et a1. (1978). Monsen and Balintfy (1982) reviewed the important effects of enhancing factors upon the absorption of non-heme iron, inorganic iron salts, found in foods of low iron availability. Ascorbic acid, meats, fish and poultry, when consumed with low iron availability foods, enhance the amount of non-heme iron absorbed. Mertz (1980) stated that the interactions of iron provide a tool to increase iron absorption and to decrease available iron in patients at risk of iron overload.

The aqueous environment and heat during preparation are conducive to the formation of complexes between iron and some food constituents (Mertz, 1980). Several of the previous investigators tended to agree that the acidity and the cooking time affect the increase in iron content of foods when cooked in iron utensils (Mackay et a1., 1945; Moore, 1965; White, 1969; Burroughs and Chan, 1972). Previous studies do not provide clear explanations of methodology and do not have more than one replication of their experiment (Mackav 
et al., 1945; Moore, 1965; Monsen et a1., 1967). Burroughs and Chan (1972) performed the only extensive comparison study of the increased iron content of food prepared in iron utensils and in non-iron utensils; however, the baseline iron content of the food was calculated and not analyzed. In many of the other studies, research on iron content of food cooked in iron utensils was performed only as a smaller portion of a larger study (Mackay et a1., 1945; Bothwell et al., 1964; Moore, 1965; Monsen et a1., 1967; White, 1969; Lal et a1., 1973). There is no current information on the use of iron cookware. Therefore, information on the current use of iron cookware and the amount of iron in a variety of foods cooked in iron utensils needs to be obtained. 
CHAPTER II

METHODS AND MATERIALS

\section{Use of Iron Utensils Survey}

Information concerning the current use of iron cooking utensils was obtained by surveys conducted at the 1982 Panhandle South Plains Fair in Lubbock, Texas, and the 1982 American Dietetic Association Convention in San Antonio, Texas. Both surveys were conducted in October, 1982 .

A questionnaire (Appendix A) was developed from the previous study on the use of iron cookware by White (1968). White surveyed a total of 433 persons from two women's church organizations in a Chicago suburb, the Chicago Nutrition Association, and the 1967 meetings of the American Home Economics Association and the American Dietetic Association. Because the survey questions and groups were similar, data obtained from this research can serve as a follow-up to the study done by White in 1968 .

The questionnaire was pilot-tested before the actual survey. The questionnaire was given to a group of persons numbering over $10 \%$ of the size of the study sample and who were similar in characteristics to the study sample, dietitians and students who live in the Lubbock, Texas area.

There were 182 questionnaires completed at the 1982 Panhandle South Plains Fair (Appendix A). A booth in the Commercial Exhibit Building at the Fair was obtained for the four surveyors, three 
undergraduate university students and one graduate student, to survey the subjects as they viewed the exhibits. A sign with "Texas Tech University, Department of Food and Nutrition" was used at the booth. The four surveyors included one Hispanic student, one Black student, and two Caucasian students. The three undergraduate students were trained by the graduate student researcher. Fach student surveyor had the opportunity to ask another surveyor the questions from the questionnaire. Guidelines for questioning and reporting responses were agreed upon. The surveyors asked the subjects at the Fair if they would answer some questions on iron cookware. The subjects were questioned and their responses were recorded on the questionnaires by the surveyors. An unbiased attempt was made by the surveyors to question approximately every third person who passed the booth.

The questionnaire was revised following the Fair survey, mainly to arrange socioeconomic questions together. The revised questionnaire (Appendix B) was distributed by the researcher in the rest area at the 1982 American Dietetic Association Convention Exhibits. The researcher attempted to distribute the questionnaire in an unbiased manner. The subjects completed the questionnaires and returned them to the researcher. There were 184 questionnaires completed at the Convention. It was believed that all three ethnic groups, Caucasian, Hispanic and Black, in the Lubbock area (Brittin, 1974) would be represented at the Panhandle South Plains Fair and that a nationwide sample could be obtained at the American Dietetic Association Convention. 


\section{Iron in Food Study}

Twenty foods were cooked in iron and in non-iron utensils to compare the iron content of the foods due to cooking in iron utensils. The cast-iron skillet was used because it was the most commonly used iron utensil by persons who use iron cookware, according to the present survey and to that by white (1968). Two new, seasoned, 9-inch iron skillets were used. The skillet used throughout the study had been used several times a day for about two weeks prior to this study. The second skillet, which had been used fewer times prior to the study, was used to cook three foods (spaghetti sauce, applesauce and scrambled eggs) to test the variability of iron content in foods when cooked in different iron skillets. Moore (1965) found these three foods to have great increases in iron when cooked in iron utensils. The non-iron utensil used was a 9-inch Corningware dish.

The three treatments of each food analyzed for iron content included raw, cooked in iron utensil, and cooked in non-iron utensil. Three replications were prepared of the three treatments for each food.

The twenty foods selected included foods frequently cooked in iron utensils by most people, as determined from the present survey. The foods also included foods from each food group and foods previously studied for iron content when cooked in iron utensils (Moore, 1965; Monsen et al., 1967; Burroughs and Chan, 1972).

$\$ 11$ foods were purchased at the same time and prepared within a period of ten days. Common cooking methods and recipes were used (Appendix C). Weights before cooking and cooking times were controlled 
throughout all of the replications for each food. Cooked weights were recorded to determine yield. Each food sample was blended in a glass blender, the $\mathrm{pH}$ was determined, and the sample was stored in a plastic freezer bag and frozen. Before freezing, pH was determined for each treatment. Cooking data (weight and time) and $\mathrm{pH}$ were recorded on the food cooking record (Appendix D). Careful preparation of the foods and careful utensil cleaning procedures minimized iron contamination from water or utensils. All utensils were thoroughly washed after each replication in a sink of fresh hot water and detergent, rinsed two times with running cold tap water in the adjacent sink, rinsed in two pans of deionized water, and placed on a rack to air dry. The deionized water used in cooking and cleaning contained negligible amounts of iron.

For analysis, the frozen samples were thawed in a refrigerator and each sample was blended again to make it homogeneous in consistency. Duplicate samples were dried, ashed, and analyzed for moisture and iron content using AOAC (1980) methods. Two $5 \mathrm{~g}$ samples were taken from the center of each of the blended food samples and placed in acid-rinsed, air-dried procelain crucibles with lids. Moisture content was determined by drying the six $5 \mathrm{~g}$ samples of each food plus an empty crucible with lid in a drying oven at $100-102^{\circ} \mathrm{C}$ until constant weight was achieved in approximately 17-20 hours. Final constant weights were adjusted for moisture loss from the empty crucible. Dry ashing was used. Three drops of pure olive oil were added to each crucible and heated on a hot plate set for medium temperature, until 
swelling stopped, for 15 minutes. The six samples plus the blank were then ashed in the muffle furnance at $425^{\circ} \mathrm{C}$ until white ash was obtained (overnight). The ashing temperature of $425^{\circ} \mathrm{C}$ was used rather than $525^{\circ} \mathrm{C}$ stated in the AOAC method because in dry ashing some iron loss may occur because iron volatilizes as ferric chloride at $450^{\circ} \mathrm{C}$ (Pomeranz and Meloan, 1978). Ash was then moistened with $1 \mathrm{ml}$ of deionized water and dried on a $250^{\circ} \mathrm{C}$ steam bath for 15 minutes, dried on a hot plate on medium temperature for 15 minutes, and then re-ashed in the muffle furnance at $425^{\circ} \mathrm{C}$ to constant weight ( 2 hours). The ashes were dissolved in $15 \mathrm{ml}$ of $20 \%$ nitric acid and filtered through No. 42 (ashless) Whatman filter paper into volumetric flasks. The residue and paper were rinsed three times with $3 \mathrm{ml}$ deionized water each time. Either 50 or $100 \mathrm{ml}$ volumetric flasks were used, depending on the calculated concentration of iron in the food (USDA, 1963; USDA, 1976-1982). The filtered samples were analyzed for iron content by flame atomic absorption spectrophotometry on a Perkin Elmer Model 5000 atomic absorption spectrophotometer, at a wavelength of $248.3 \mathrm{~nm}$ and slit setting of $0.2 \mathrm{~nm}$ (Perkin-Elmer, 1980). Iron content of the samples was measured against the iron standard, 1000 ppm atomic absorption standard, ferric chloride, which was diluted to 5 ppm iron with. 180 absorbance.

All glassware was cleaned carefully to prevent iron contamination. Glassware was washed in hot sudsy water, rinsed with tap water and then with deionized water, soaked in distilled water with diluted hydrochloric acid, rinsed twice with deionized water and air dried. Acid reagents used (nitric acid and hydrochloric acid) contained 
minimal iron. Deionized water was distilled water which was run through a deionizing column; it contained minimal iron.

A recovery study was performed with the blended raw pancake batter because of its homogeneity. Six $5 \mathrm{~g}$ samples of the pancake batter were weighed out. Ferric chloride standard $(1 \mathrm{ml})$ was added to each of the three samples and deionized water $(1 \mathrm{ml})$ was added to each of the other three samples. The samples were dried, ashed and analyzed for iron content according to the stated procedure. Recovery of the added ferric chloride standard was 98.5 percent.

\section{Statistical Methods}

Chi-square procedures (Nie et al., 1975) were used to analyze the discrete variables from the questionnaires. Analysis of variance was used to analyze the continuous data obtained from the questionnaires in the use of iron utensils survey.

The design of the iron in food study was factorial: 20 foods $x$ 3 treatments $\times 3$ replications $\times 2$ samples. The design included 4 treatments and 3 foods in the part of the study in which two different iron skillets were used. The method of least squares analysis of variance (Harvey, 1960) was used to determine the effects of the main factors (food, treatment, replication and sample) and of the two-factor interactions on the continuous dependent variables. Duncan's Multiple Range Test used to test the difference between appropriate means when the analysis of variance showed a significant effect in a main factor. Relationships between $\mathrm{pH}$ of raw food, moisture, and iron content were determined by simple correlation coefficients. 
CHAPTER III

RESULTS AND DISCUSSION

Use of Iron Utensils Survey

Questionnaires obtained from the survey numbered 182 from the Fair and 184 from the Convention. Results of the survey for the two samples are shown in Table 1 . The main results regarding cooking variables are the following. Most of the subjects (80\%) indicated that they prepare most of their own meals. Most of the subjects (79\%) owned iron cookware. Most of the subjects (61\%) said that the utensil used most often was the skillet while $30 \%$ said it was the saucepan. More subjects indicated that the utensil used most often was made of stainless steel (36\%) than any other material; iron was the second most popular material with $22 \%$ of the subjects stating that the utensil used most often was made of iron. Most of the subjects $(72 \%)$ use iron cookware. More of the subjects (41\%) said that they owned one kind of iron utensil, $21 \%$ owned none, and $21 \%$ owned two kinds. The kind of iron utensil owned by the most people (75\%) was the skillet. Nineteen percent of the subjects owned an iron griddle, $19 \%$ owned an iron cornstick mold, $20 \%$ owned an iron Dutch oven, $8 \%$ owned an iron muffin pan, and $7 \%$ owned other iron utensils. Although $25 \%$ of the subjects said they never use the iron skillet, $25 \%$ said they use it several times per week and $23 \%$ said they use it daily. Iron utensils other than the skillet were used by few people; most of the subjects ( $56 \%$ ) never used them and $25 \%$ seldom used them. 
TABLE 1: Test for Independence for Fair and Convention Samples and Discrete Variables in the Use of Iron Utensils Survey

\begin{tabular}{|c|c|c|c|c|c|}
\hline \multirow[b]{2}{*}{ Variable } & \multicolumn{3}{|c|}{ Sample } & \multirow[b]{2}{*}{$\mathrm{df}$} & \multirow{2}{*}{$\begin{array}{l}\text { Chi- } \\
\text { square } \\
\text { value }\end{array}$} \\
\hline & Fair & Convention & Total & & \\
\hline & \multicolumn{3}{|c|}{ Number of subjects } & & \\
\hline \multicolumn{6}{|l|}{ Prepare most of own meals } \\
\hline No & 28 & 45 & 73 & 1 & $4.16 \%$ \\
\hline Yes & 154 & 139 & 293 & & \\
\hline \multicolumn{6}{|l|}{ Own iron cookware } \\
\hline No & 37 & 40 & 77 & 1 & 0.04 \\
\hline Yes & 145 & 144 & 289 & & \\
\hline \multicolumn{6}{|l|}{ Utensil used most often } \\
\hline Skillet & 142 & 81 & 223 & 4 & $49.24 \therefore \%$ \\
\hline Saucepan & 29 & 81 & 110 & & \\
\hline Dutch oven & 1 & 4 & 5 & & \\
\hline Roaster & 0 & 6 & 6 & & \\
\hline Other & 10 & 12 & 22 & & \\
\hline \multicolumn{6}{|l|}{$\begin{array}{l}\text { Utensil used most often is } \\
\text { made of }\end{array}$} \\
\hline Aluminum & 29 & 36 & 65 & 6 & $27.69 * \div$ \\
\hline Stainless steel & 48 & 83 & 131 & & \\
\hline Glass & 2 & 1 & 3 & & \\
\hline Corning & 14 & 8 & 22 & & \\
\hline Iron & 42 & 39 & 81 & & \\
\hline Enamel & 3 & 3 & 6 & & \\
\hline Other & 44 & 14 & 58 & & \\
\hline \multicolumn{6}{|l|}{ Use iron cookware } \\
\hline No & 49 & 54 & 103 & 1 & 0.16 \\
\hline Yes & 133 & 130 & 263 & & \\
\hline \multicolumn{6}{|l|}{ Number of kinds of } \\
\hline $\begin{array}{l}\text { Iron ucensils owned } \\
0\end{array}$ & 37 & 40 & 77 & 6 & 5.60 \\
\hline 1 & 67 & 83 & 150 & & \\
\hline 2 & 39 & 36 & 75 & & \\
\hline 3 & 18 & 13 & 31 & & \\
\hline 4 & 10 & 7 & 17 & & \\
\hline 5 & 8 & 4 & 12 & & \\
\hline 6 or more & 3 & 1 & 4 & & \\
\hline
\end{tabular}


TABLE 1 - Continued

\begin{tabular}{|c|c|c|c|c|c|}
\hline \multirow[b]{2}{*}{ Variable } & \multicolumn{3}{|c|}{ Sample } & \multirow[b]{2}{*}{$d f$} & \multirow{2}{*}{$\begin{array}{l}\text { Chi- } \\
\text { square } \\
\text { value }\end{array}$} \\
\hline & Fair & Convention & Total & & \\
\hline & \multicolumn{3}{|c|}{ Number of subjects } & & \\
\hline \multicolumn{6}{|l|}{$\begin{array}{l}\text { Iron utensils owned } \\
\text { None }\end{array}$} \\
\hline No & 145 & 144 & 289 & 1 & 0.04 \\
\hline Yes & 37 & 40 & 77 & & \\
\hline \multicolumn{6}{|l|}{ Skillet } \\
\hline No & 41 & 52 & 93 & 1 & 1.30 \\
\hline Yes & 141 & 132 & 273 & & \\
\hline \multicolumn{6}{|l|}{ Griddle } \\
\hline No & 144 & 154 & 298 & 1 & 0.98 \\
\hline Yes & 38 & 30 & 68 & & \\
\hline \multicolumn{6}{|l|}{ Cornstick mold } \\
\hline No & 148 & 149 & 297 & 1 & 0.00 \\
\hline Yes & 34 & 35 & 69 & & \\
\hline \multicolumn{6}{|l|}{ Dutch oven } \\
\hline No & 141 & 152 & 293 & 1 & 1.21 \\
\hline Yes & 41 & 32 & 73 & & \\
\hline \multicolumn{6}{|l|}{ Muffin pan } \\
\hline No & 164 & 173 & 337 & 1 & 1.42 \\
\hline Yes & 18 & 11 & 29 & & \\
\hline \multicolumn{6}{|l|}{ Other } \\
\hline No & 164 & 176 & 340 & 1 & 3.46 \\
\hline Yes & 18 & 8 & 26 & & \\
\hline \multicolumn{6}{|l|}{ Use iron skillet } \\
\hline Never & 51 & 41 & 92 & 4 & $27.37 * \star$ \\
\hline Seldom & 22 & 34 & 56 & & \\
\hline $2-3$ times/month & 15 & 28 & 43 & & \\
\hline $2-3$ times/week & 34 & 56 & 90 & & \\
\hline Daily & 60 & 25 & 85 & & \\
\hline \multicolumn{6}{|l|}{$\begin{array}{l}\text { Use iron utensils other } \\
\text { than skillet }\end{array}$} \\
\hline Never & 110 & 94 & 204 & 4 & 5.23 \\
\hline Seldom & 39 & 51 & 90 & & \\
\hline Every week & 8 & 15 & 23 & & \\
\hline 2 or 3 times/week & 15 & 16 & 31 & & \\
\hline Daily & 10 & 8 & 18 & & \\
\hline
\end{tabular}


TABLE 1 - Continued

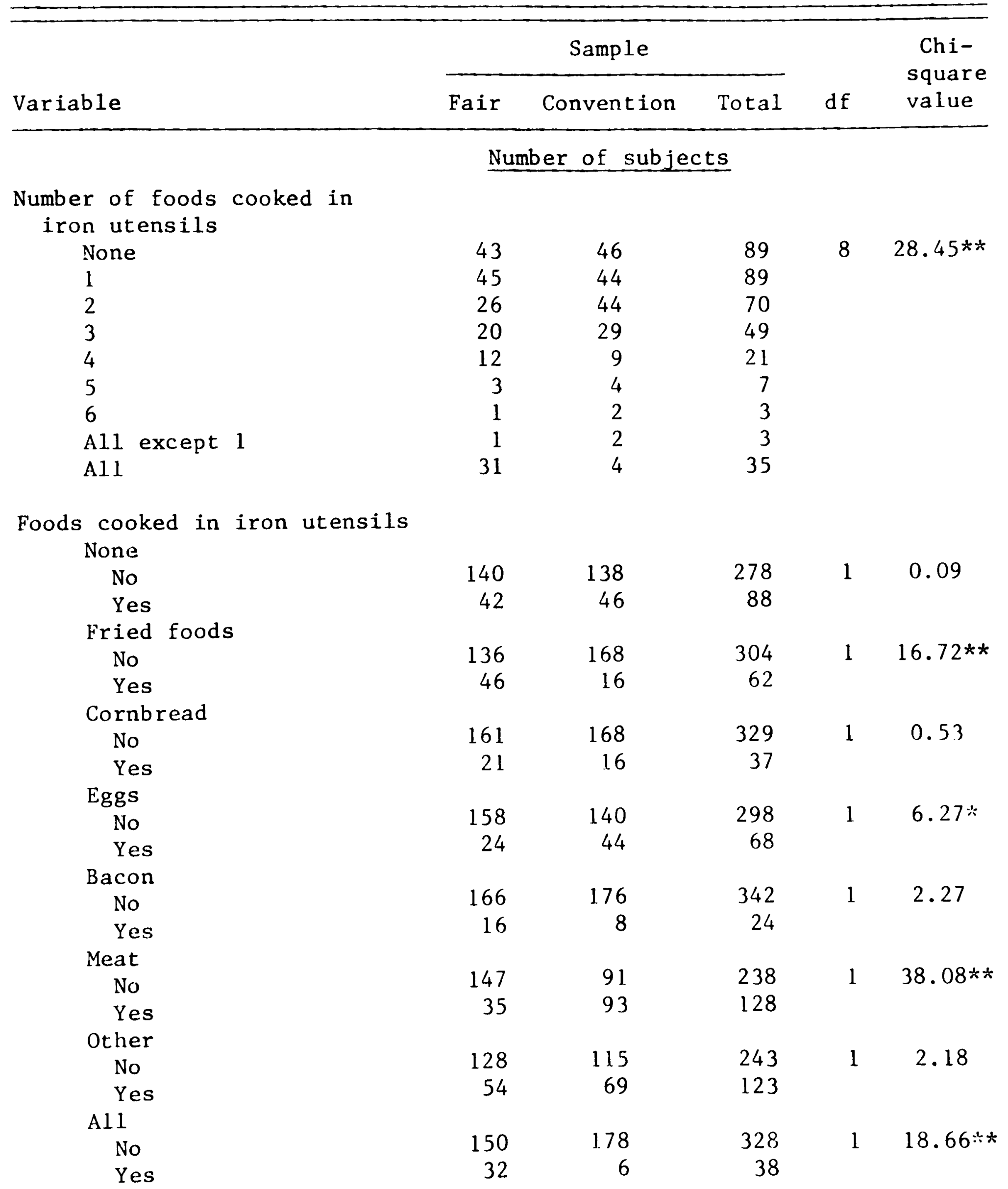


TABLE 1 - Continued

\begin{tabular}{|c|c|c|c|c|c|}
\hline \multirow[b]{2}{*}{ Variable } & \multicolumn{3}{|c|}{ Sample } & \multirow[b]{2}{*}{$\mathrm{df}$} & \multirow{2}{*}{$\begin{array}{l}\text { Chi- } \\
\text { square } \\
\text { value }\end{array}$} \\
\hline & Fair & Convention & Total & & \\
\hline & \multicolumn{3}{|c|}{ Number of subjects } & & \\
\hline \multicolumn{6}{|c|}{$\begin{array}{l}\text { Use of iron cookware compared } \\
\text { to use } 5 \text { to } 10 \text { years ago }\end{array}$} \\
\hline Lot less & 50 & 39 & 89 & 4 & $28.29 * *$ \\
\hline Slightly less & 33 & 24 & 57 & & \\
\hline Same, no change & 65 & 103 & 168 & & \\
\hline Slightly more & 7 & 13 & 20 & & \\
\hline Lot more & 27 & 5 & 32 & & \\
\hline \multicolumn{6}{|c|}{$\begin{array}{l}\text { Use of iron cookware compared } \\
\text { to use in childhood home }\end{array}$} \\
\hline Less & 107 & 104 & 211 & 2 & 2.36 \\
\hline Same & 44 & 56 & 100 & & \\
\hline More & 31 & 24 & 55 & & \\
\hline \multicolumn{6}{|l|}{ Own and use microwave oven } \\
\hline No & 89 & 95 & 184 & 1 & 0.17 \\
\hline Yes & 93 & 89 & 182 & & \\
\hline \multicolumn{6}{|l|}{$\begin{array}{l}\text { Use of iron cookware since } \\
\text { acquiring microwave oven }\end{array}$} \\
\hline Less & 31 & 37 & 68 & 3 & 4.14 \\
\hline Same & 61 & 54 & 115 & & \\
\hline More & 3 & 0 & 3 & & \\
\hline Do not own microwave & 87 & 93 & 180 & & \\
\hline \multicolumn{6}{|l|}{ Sex } \\
\hline Male & 30 & 6 & 36 & 1 & $16.58 * *$ \\
\hline Female & 152 & 1.78 & 330 & & \\
\hline \multicolumn{6}{|l|}{ Age } \\
\hline No answer & 1 & 7 & 8 & 5 & $24.99 * *$ \\
\hline 18 or less & 3 & 0 & 3 & & \\
\hline $19-22$ & 16 & 6 & 22 & & \\
\hline $23-50$ & 128 & 120 & 248 & & \\
\hline $51-69$ & 28 & 51 & 79 & & \\
\hline 70 or more & 6 & 0 & 6 & & \\
\hline \multicolumn{6}{|l|}{ Marital status } \\
\hline Married & 139 & 105 & 244 & 1 & $14.49 * x$ \\
\hline Single & 43 & 79 & 122 & & \\
\hline
\end{tabular}


TABLE 1 - Continued

\begin{tabular}{|c|c|c|c|c|c|}
\hline \multirow[b]{2}{*}{ Variable } & \multicolumn{3}{|c|}{ Sample } & \multirow[b]{2}{*}{$\mathrm{dE}$} & \multirow{2}{*}{$\begin{array}{l}\text { Chi- } \\
\text { square } \\
\text { value }\end{array}$} \\
\hline & Fair & Convention & Total & & \\
\hline & \multicolumn{3}{|c|}{ Number of subjects } & & \\
\hline \multicolumn{6}{|l|}{ Ethnic group } \\
\hline Caucasian & 151 & 165 & 316 & 3 & $33.23 * *$ \\
\hline Hispanic & 24 & 0 & 24 & & \\
\hline Black & 6 & 8 & 14 & & \\
\hline Other & 1 & 11 & 12 & & \\
\hline \multicolumn{6}{|l|}{$\begin{array}{l}\text { Number in family that you } \\
\text { cook for }\end{array}$} \\
\hline 1 & 28 & 65 & 93 & 4 & $24.32 * *$ \\
\hline 2 & 49 & 53 & 102 & & \\
\hline 3 & 42 & 26 & 68 & & \\
\hline 4 & 35 & 24 & 59 & & \\
\hline 5 or more & 28 & 16 & 44 & & \\
\hline \multicolumn{6}{|l|}{ Occupation } \\
\hline Dietitian & 0 & 124 & 124 & 4 & $213.61 * *$ \\
\hline Housewife & 45 & 8 & 53 & & \\
\hline Professor, teacher & 14 & 12 & 26 & & \\
\hline Student & 10 & 18 & 28 & & \\
\hline Other & 113 & 22 & 135 & & \\
\hline \multicolumn{6}{|l|}{ Education } \\
\hline Less than high school & 26 & 0 & 26 & 4 & $195.87 * *$ \\
\hline High school & 55 & 2 & 57 & & \\
\hline Some college & 58 & 7 & 65 & & \\
\hline Finished college & 28 & 99 & 127 & & \\
\hline Graduate study & 15 & 76 & 91 & & \\
\hline \multicolumn{6}{|l|}{ Education of spouse } \\
\hline Less than high school & 26 & 0 & 26 & 5 & $95.61 * *$ \\
\hline High school & 41 & 10 & 51 & & \\
\hline Some college & 37 & 10 & 47 & & \\
\hline Finished college & 24 & 40 & 64 & & \\
\hline Graduate study & 11 & 45 & 56 & & \\
\hline No spouse & 43 & 79 & 122 & & \\
\hline
\end{tabular}


TABLE 1 - Continued

\begin{tabular}{|c|c|c|c|c|c|}
\hline \multirow[b]{2}{*}{ Variable } & \multicolumn{3}{|c|}{ Sample } & \multirow[b]{2}{*}{$\mathrm{df}$} & \multirow{2}{*}{$\begin{array}{l}\text { Chi- } \\
\text { squar } \\
\text { value }\end{array}$} \\
\hline & Fair & Convention & Total & & \\
\hline & \multicolumn{3}{|c|}{ Number of subjects } & & \\
\hline \multicolumn{6}{|l|}{ Income } \\
\hline No answer & 24 & 26 & 50 & 5 & $28.62 * *$ \\
\hline Less than $\$ 10,000$ & 13 & 4 & 17 & & \\
\hline$\$ 10,000-24,999$ & 65 & 41 & 106 & & \\
\hline$\$ 25,000-49,999$ & 65 & 65 & 130 & & \\
\hline$\$ 50,000-74,999$ & 11 & 39 & 50 & & \\
\hline$\$ 75,000$ or more & 4 & 9 & 13 & & \\
\hline
\end{tabular}

$* \mathrm{P}<0.05$.

$\therefore * \mathrm{P}<0.01$. 
Although $24 \%$ of the subjects said they cook no foods in iron utensils, $76 \%$ of the subjects said they cook foods in iron utensils; $24 \%$ cook one food in iron utensils, $19 \%$ cook two, $13 \%$ cook three, and $10 \%$ cook all foods in iron utensils. The foods cooked in iron utensils named by the subjects were: none (by $24 \%$ of the subjects), meat (by $35 \%$ ), eggs (19\%), fried foods ( $17 \%)$, cornbread (10\%), all (10\%), bacon ( $7 \%)$; other foods were named by $34 \%$. Regarding change in use of iron cookware during the past 5 to 10 years, more subjects (46\%) indicated no change than any other response, although $24 \%$ said they now use iron cookware a lot less and $9 \%$ said they use it a lot more. Regarding use of iron cookware compared to use in childhood home, most of the subjects (58\%) said current use is less, although $27 \%$ said it is the same and $15 \%$ said it is more. One-half of the subjects own and use a microwave oven. Because iron utensils cannot be used in microwave cooking, it was hypothesized that the use of the microwave oven might have resulted in decreased use of iron cookware; however, of the $50 \%$ of the subjects who own a microwave oven, $62 \%$ said their use of iron cookware is the same since the acquisition of a microwave oven and $37 \%$ said their use of iron cookware is less.

The main results regarding socioeconomic variables are the following. Most of the subjects ( $90 \%$ ) were females. Most of the subjects (68\%) were 23 to 50 years in age; $22 \%$ were 51 to 69 years in age. Twothirds of the subjects were married. Most of the subjects (86\%) were Caucasian. Most subjects said that the number of persons in the family cooked for was one (25\%) or two (28\%), although $12 \%$ said they cooked for 
5 or more persons. The occupation listed by most subjects was dietitian (34\%), followed by housewife (15\%), student ( $8 \%$ ), and professor or teacher ( $7 \%$ ); other occupations were 1isted by $37 \%$. About one-third (35\%) of the subjects stated that the highest education completed was college, while $25 \%$ indicated graduate study. Although one-third of the subjects had no spouse, the education of spouse of the remaining subjects was fairly similar to that of the subjects $(26 \%$ completed college and $23 \%$ had graduate study). More subjects had an annual family income of $\$ 25,000-49,999$ than any other category; $35 \%$ of the subjects for each sample (Fair and Convention) and for the total were in this income category.

Chi-square analysis was used to test the null hypothesis that there were no significant differences in the responses to the questions by the two samples. The comparison of the responses is shown in Table 1. Chi-square analysis indicated that the following 17 variables were not independent $(\mathrm{P}<0.01)$ of sample: utensil used most often, what the utensil used most often is made of, frequency of use of iron skillet, number of foods cooked in iron utensils, fried foods cooked in iron utensils, meat cooked in iron utensils, all foods cooked in iron utensils, change in the use of iron cookware in the past 5 to 10 years, sex, age, marital status, ethnic group, number in family that are cooked for, occupation, education, education of spouse, and income. Also, the following two variables were not independent $(P<0.05)$ of sample: prepare most of own meals and eggs cooked in iron utensils.

The main differences in the variables which were significantly 
different for the two samples are summarized as follows. More of the Fair subjects prepared their own meals than the Convention subjects. The skillet and saucepan were equally selected ( $44 \%$ each) as the utensil used most often by the Convention sample, while the skillet was the utensil used most often by the Fair sample (78\%). The largest number of Convention and Fair subjects stated that the most used utensil was made of stainless steel with more Convention ( $45 \%$ ) than Fair subjects (26\%) stating that the utensil used most often was made of stainless steel. Thirty-three percent of the Fair sample used the iron skillet daily while only $14 \%$ of the Convention sample used the iron skillet daily. Seventeen percent of the Fair sample and only $2 \%$ of the Convention sample cooked all foods in iron utensils. A smaller percentage of the Convention subjects cooked fried foods and all foods in iron utensils than the Fair subjects, while a larger percentage of Convention than Fair subjects cooked eggs and meat in iron utensils.

The number of subjects in the Fair sample tended to collect more at the extremes for the change in the use of iron utensils in the past 5 to 10 years, compared to the Convention subjects. Fifty-six percent of the convention subjects indicated no change in the use of iron utensils during the past 5 to 10 years, while only $36 \%$ of the Fair subjects indicated no change.

More of the Fair subjects (17\%) than of the Convention subjects (3\%) were male. Although most subjects in both samples were in the 23-50 age group (65\% of the Convention sample and $70 \%$ of the Fair sample), more of the Convention subjects were in the older age groups 
and fewer were in the younger age groups than the Fair subjects. Fewer Convention subjects were married than Fair subjects. The main differences in ethnic group of the two samples were that more Hispanics were surveyed at the Fair (24) than at the Convention (0), while more subjects (11) at the Convention than at the Fair (1) were in other groups not listed. More Convention subjects had families of one which they cooked for, while more Fair subjects had larger families, of 3 or more. Main differences in occupation of the two samples were that the Convention sample contained mostly dietitians $(67 \%)$, while the Fair sample contained none, the Convention sample contained more students (18) than the Fair sample (10) and the Fair sample contained more subjects with occupations of housewife or other occupations not listed (62\%). The Convention sample and their spouses had more education than the Fair sample and their spouses. The Convention sample had generally higher incomes than the Fair sample.

Chi-square analysis showed that the Fair versus the Convention sample was independent of the variables: own iron cookware, use of iron cookware, number of kinds of iron utensils owned, which iron utensils were owned, the use of iron utensils other than the skillet, foods cooked in iron (none, cornbread, bacon, and other foods), current use of iron utensils compared to childhood home, own microwave oven, and change in the use of iron utensils since the acquisition of the microwave oven. Thus, most variables related to cooking (10 of 18) did not differ significantly for the two samples while all (9) of the socioeconomic variables differed significantly for the two samples. 
Because chi-square analysis showed that the Fair versus the Convention sample responses to most of the questions on current use of iron utensils were independent, the null hypothesis was accepted for most of the independent variables of the Fair versus the Convention sample. Least squares means for the two samples and the continuous socioeconomic variables of age, number in family, education, education of spouse, and annual family income are shown in Table 2. Analysis of variance showed that the means for each variable for the Fair versus Convention sample differed significantly $(\mathrm{P}<0.01)$. The Fair sample was younger ( 37.7 versus 42.1 years) and had more people in the family (3.1 versus 2.4), less education (13.2 versus 16.9 years) and less income $(\$ 27,158$ versus $\$ 39,354)$ than the Convention sample. Also, education of spouse was less for the Fair sample (13.1 versus 16.8).

The distribution and percent of the Convention subjects by state are shown in Table 3. Because the American Dietetic Association Convention was a national meeting, a national sample was hoped to be obtained. Thirty-one states, the District of Columbia, and the country of Mexico were represented. The largest number of subjects was from Texas, as was expected because the Convention was held in Texas.

The 366 questionnaires from the survey were analyzed by chisquare analysis to test the null hypothesis that there is no significant difference in the responses to the questions between subjects who use iron cookware and subjects who do not use iron cookware. The comparison of the responses of the subjects who use iron utensils and those who do not for discrete variables is shown in Table 4. 
TABLE 2: Least Squares Means for Continuous Socioeconomic Data for Fair and Convention Samples

\begin{tabular}{|c|c|c|c|c|c|}
\hline Sample & $\begin{array}{c}\text { Age } \\
\text { (years) }\end{array}$ & $\begin{array}{l}\text { Number } \\
\text { in } \\
\text { family }\end{array}$ & $\begin{array}{l}\text { Education } \\
\text { (years) }\end{array}$ & $\begin{array}{l}\text { Education } \\
\text { of spouse } \\
\text { (years) }\end{array}$ & $\begin{array}{c}\text { Annua } 1 \\
\text { family } \\
\text { income } \\
(\$)\end{array}$ \\
\hline Fair & $37.7^{\mathrm{a}}$ & 3.1 & 13.2 & 13.1 & 27,158 \\
\hline Convention & 42.1 & 2.4 & 16.9 & 16.8 & 39,354 \\
\hline
\end{tabular}


TABLE 3: Distribution and Percent of the Convention Sample by State

\begin{tabular}{|c|c|c|c|c|c|}
\hline & Number & $\underline{\%}$ & & Number & $\underline{\%}$ \\
\hline Alabama & 3 & 1.6 & Montana & 0 & --- \\
\hline Alaska & 0 & --- & Nebraska & 3 & 1.6 \\
\hline Arizona & 0 & --- & Nevada & 0 & --- \\
\hline Arkansas & 0 & --- & New Hampshire & 0 & -- \\
\hline California & 12 & 6.5 & New Jersey & 7 & 3.8 \\
\hline Colorado & 1 & 0.5 & New Mexico & 0 & --- \\
\hline Connecticut & 2 & 1.1 & New York & 5 & 2.7 \\
\hline Delaware & 0 & --- & North Carolina & 0 & --- \\
\hline F1orida & 3 & 1.6 & North Dakota & 0 & -- \\
\hline Georgia & 2 & 1.1 & Ohio & 3 & 1.6 \\
\hline Hawaii & 0 & --- & Oklahoma & 3 & 1.6 \\
\hline Idaho & 0 & --- & Oregon & 3 & 1.6 \\
\hline Illinois & 10 & 5.4 & Pennsylvania & 0 & -- \\
\hline Indiana & 4 & 2.2 & Rhode Is land & 1 & 0.5 \\
\hline Iowa & 1 & 0.5 & South Carolina & 3 & 1.6 \\
\hline Kansas & 8 & 4.3 & South Dakota & 2 & 1.1 \\
\hline Kentucky & 2 & 1.1 & Tennessee & 8 & 4.3 \\
\hline Louisiana & 0 & --- & Texas & 64 & 35.0 \\
\hline Maine & 3 & 1.6 & Utah & 0 & --- \\
\hline Maryland & 6 & 3.3 & Vermont & 0 & --- \\
\hline Massachusetts & 3 & 1.6 & Virginia & 4 & 2.2 \\
\hline Michigan & 7 & 3.8 & Washington & 1 & 0.5 \\
\hline Minnesota & 3 & 1.6 & West Virginia & 0 & --- \\
\hline Mississippi & 0 & -- & Wisconsin & 1 & 0.5 \\
\hline \multirow[t]{2}{*}{ Missouri } & 3 & 1.6 & Wyoming & $\underline{0}$ & -- \\
\hline & & & Total & 184 & 99.6 \\
\hline
\end{tabular}

a plus District of Columbia, $2(1.1 \%)$ and Mexico, $1(0.5 \%)$. 
TABLE 4: Test for Independence for the Use of Iron Cookware and for Discrete Variables

\begin{tabular}{|c|c|c|c|c|c|}
\hline \multirow[b]{2}{*}{ Variable } & \multicolumn{3}{|c|}{ Use iron cookware } & \multirow[b]{2}{*}{$\mathrm{df}$} & \multirow{2}{*}{$\begin{array}{l}\text { Chi- } \\
\text { square } \\
\text { value }\end{array}$} \\
\hline & No & Yes & Total & & \\
\hline & \multicolumn{3}{|c|}{ Number of subjects } & & \\
\hline \multicolumn{6}{|l|}{ Sample } \\
\hline Fair & 49 & 133 & 182 & 1 & 0.16 \\
\hline Convention & 54 & 130 & 184 & & \\
\hline \multicolumn{6}{|c|}{ Prepare most of own meals } \\
\hline No & 19 & 54 & 73 & 1 & 0.09 \\
\hline Yes & 84 & 209 & 293 & & \\
\hline \multicolumn{6}{|l|}{ Own iron cookware } \\
\hline No & 76 & 1 & 77 & 1 & $235.68 * *$ \\
\hline Yes & 27 & 262 & 289 & & \\
\hline \multicolumn{6}{|l|}{ Utensil used most often } \\
\hline Skillet & 59 & 164 & 223 & 4 & 4.75 \\
\hline Saucepan & 33 & 77 & 110 & & \\
\hline Dutch oven & 3 & 2 & 5 & & \\
\hline Roaster & 3 & 3 & 6 & & \\
\hline other & 5 & 17 & 22 & & \\
\hline \multicolumn{6}{|c|}{$\begin{array}{l}\text { Utensil used most often } \\
\text { is made of }\end{array}$} \\
\hline Aluminum & 25 & 40 & 65 & 6 & $47.20 * *$ \\
\hline Stainless steel & 45 & 86 & 131 & & \\
\hline Gilass & 0 & 3 & 3 & & \\
\hline Corning & 5 & 17 & 22 & & \\
\hline Iron & 0 & 81 & 81 & & \\
\hline Ename 1 & 2 & 4 & 6 & & \\
\hline Other & 26 & 32 & 58 & & \\
\hline
\end{tabular}

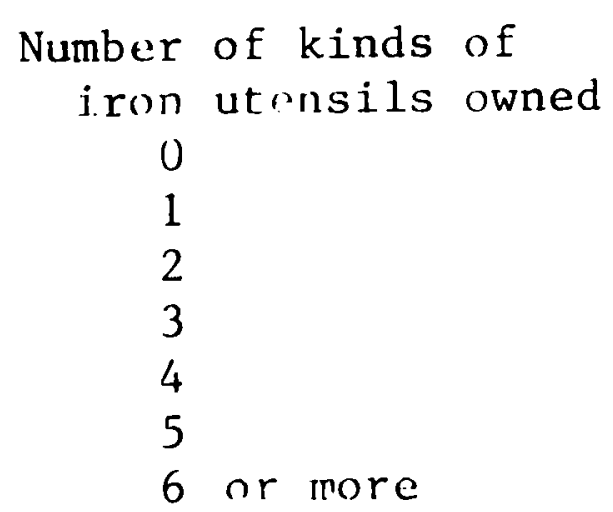

$\begin{array}{rrrrr}77 & 0 & 77 & 6 & 250.51 * * \\ 18 & 132 & 150 & & \\ 4 & 71 & 75 & & \\ 2 & 29 & 31 & & \\ 1 & 16 & 17 & & \\ 1 & 11 & 12 & & \\ 0 & 4 & 4 & \end{array}$


TABLE 4 - Continued

\begin{tabular}{|c|c|c|c|c|c|}
\hline \multirow[b]{2}{*}{ Variable } & \multicolumn{3}{|c|}{ Use iron cookware } & \multirow[b]{2}{*}{$\mathrm{df}$} & \multirow{2}{*}{$\begin{array}{l}\text { Chi- } \\
\text { square } \\
\text { value }\end{array}$} \\
\hline & No & Yes & Total & & \\
\hline & \multicolumn{3}{|c|}{ Number of subjects } & & \\
\hline \multicolumn{6}{|l|}{$\begin{array}{l}\text { Iron utensils owned } \\
\text { None }\end{array}$} \\
\hline No & 26 & 263 & 289 & \multirow[t]{2}{*}{1} & \multirow[t]{2}{*}{$244.52 * *$} \\
\hline Yes & 77 & 0 & 77 & & \\
\hline \multicolumn{6}{|l|}{ Skillet } \\
\hline No & 80 & 13 & 93 & \multirow[t]{2}{*}{1} & \multirow[t]{2}{*}{$202.73 * \star$} \\
\hline Yes & 23 & 250 & 273 & & \\
\hline \multicolumn{6}{|l|}{ Griddle } \\
\hline No & 101 & 197 & 298 & \multirow[t]{2}{*}{1} & \multirow[t]{2}{*}{$24.72 * *$} \\
\hline Yes & 2 & 66 & 68 & & \\
\hline \multicolumn{6}{|l|}{ Cornstick mold } \\
\hline No & 97 & 200 & 297 & \multirow[t]{2}{*}{1} & \multirow[t]{2}{*}{$14.74 * *$} \\
\hline Yes & 6 & 63 & 69 & & \\
\hline \multicolumn{6}{|l|}{ Dutch oven } \\
\hline No & 99 & 194 & 293 & \multirow[t]{2}{*}{1} & \multirow[t]{2}{*}{$21.78 * *$} \\
\hline Yes & 4 & 69 & 73 & & \\
\hline \multicolumn{6}{|l|}{ Muffin pan } \\
\hline No & 100 & 237 & 337 & \multirow[t]{2}{*}{1} & \multirow[t]{2}{*}{$4.02 *$} \\
\hline Yes & 3 & 26 & 29 & & \\
\hline \multicolumn{6}{|l|}{ Other } \\
\hline No & 99 & 241 & 340 & \multirow[t]{2}{*}{1} & \multirow[t]{2}{*}{1.62} \\
\hline Yes & 4 & 22 & 26 & & \\
\hline \multicolumn{6}{|l|}{ Use iron skillet } \\
\hline Never & 87 & 5 & 92 & \multirow[t]{5}{*}{4} & $283.42 * *$ \\
\hline Seldom & 15 & 41 & 56 & & \\
\hline 2-3 times/month & 0 & 43 & 43 & & \\
\hline $2-3$ times/week & 1 & 89 & 90 & & \\
\hline Daily & 0 & 85 & 85 & & \\
\hline $\begin{array}{l}\text { Use of other iron ute } \\
\text { other than skillet }\end{array}$ & & & & & \\
\hline Never & 95 & 109 & 204 & 4 & $78.40 * *$ \\
\hline Seldom & 7 & 83 & 90 & & \\
\hline Every weck & 0 & 23 & 23 & & \\
\hline $2-3$ times/week & 0 & 31 & 31 & & \\
\hline Daily & 1 & 17 & 18 & & \\
\hline
\end{tabular}


TABLE 4 - Continued

\begin{tabular}{|c|c|c|c|c|c|}
\hline \multirow[b]{2}{*}{ Variable } & \multicolumn{3}{|c|}{ Use iron cookware } & \multirow[b]{2}{*}{$\mathrm{df}$} & \multirow{2}{*}{$\begin{array}{l}\text { Chi- } \\
\text { square } \\
\text { value }\end{array}$} \\
\hline & No & Yes & Total & & \\
\hline
\end{tabular}

Number of foods cooked

$\begin{array}{lrrr}\text { in iron utensils } & & & \\ \text { None } & 83 & 6 & 89 \\ 1 & 15 & 74 & 39 \\ 2 & 4 & 66 & 70 \\ 3 & 1 & 48 & 49 \\ 4 & 0 & 21 & 21 \\ 5 & 0 & 7 & 7 \\ 6 & 0 & 3 & 3 \\ \text { Al1 except } 1 & 0 & 3 & 3 \\ \text { Al1 } & 0 & 35 & 35\end{array}$

Foods cooked in iron utensils None

No
Yes
Fried foods
No
Yes
Cornbread
No
Yes
Eggs
No
Yes

$8253.16 * *$

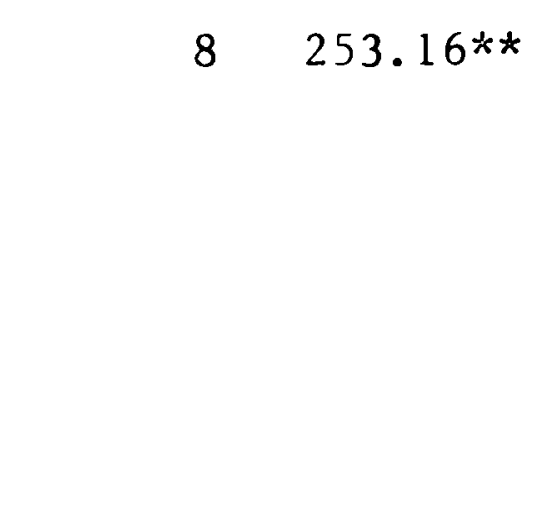

Bacon

No

Yes

$96 \quad 208$

$7 \quad 5$

304

62

$100 \quad 229$

$3 \quad 34$

329

37

88

Meat

No

Yes

Other

No

Yes

$100 \quad 198$

$3 \quad 65$

298

68

$101 \quad 241$

342

24

1238.14 *

$\triangle 11$

No

22

238

128

$19.50 * *$

$96 \quad 142$

121

243

123

$103 \quad 225$

328

38

$17.10 * *$

Yes

$0 \quad 38$

$121.84 * *$

$100 \quad 143$

120

$158.62 * \star$

3

38 
TABLE 4 - Continued

\begin{tabular}{|c|c|c|c|c|c|}
\hline \multirow[b]{2}{*}{ Variable } & \multicolumn{3}{|c|}{ Use iron cookware } & \multirow[b]{2}{*}{$d f$} & \multirow{2}{*}{$\begin{array}{l}\text { Chi- } \\
\text { square } \\
\text { value }\end{array}$} \\
\hline & No & Yes & Total & & \\
\hline & \multicolumn{3}{|c|}{ Number of subjects } & & \\
\hline \multicolumn{6}{|c|}{$\begin{array}{l}\text { Use of iron cookware compared } \\
\text { to use } 5 \text { to } 10 \text { years ago }\end{array}$} \\
\hline Lot less & 41 & 48 & 89 & 4 & $32.27 * *$ \\
\hline Slightly less & 17 & 40 & 57 & & \\
\hline Same, no change & 44 & 124 & 168 & & \\
\hline Slightly more & 0 & 20 & 20 & & \\
\hline Lot more & 1 & 31 & 32 & & \\
\hline \multicolumn{6}{|l|}{$\begin{array}{l}\text { Current use of iron cookware } \\
\text { compared to use in child- } \\
\text { hood home }\end{array}$} \\
\hline Less & 88 & 123 & 211 & 2 & $47.93 * *$ \\
\hline Same & 14 & 86 & 100 & & \\
\hline More & 1 & 54 & 55 & & \\
\hline \multicolumn{6}{|l|}{ Own and use microwave oven } \\
\hline No & 52 & 132 & 184 & 1 & 0.0 \\
\hline Yes & 51 & 131 & 182 & & \\
\hline \multicolumn{6}{|l|}{$\begin{array}{l}\text { Use of iron cookware since } \\
\text { acquiring microwave oven }\end{array}$} \\
\hline Less & 20 & 48 & 68 & 3 & 1.26 \\
\hline Same & 33 & 82 & 115 & & \\
\hline More & 0 & 3 & 3 & & \\
\hline Do not own microwave & 50 & 130 & 180 & & \\
\hline \multicolumn{6}{|l|}{ Sex } \\
\hline Male & 6 & 30 & 36 & 1 & 2.01 \\
\hline Female & 97 & 233 & 330 & & \\
\hline \multicolumn{6}{|l|}{ Age } \\
\hline No answer & 1 & 7 & 8 & 5 & $13.20 *$ \\
\hline 18 or less & 0 & 3 & 3 & & \\
\hline $19-22$ & 13 & 9 & 22 & & \\
\hline $23-50$ & 67 & 181 & 248 & & \\
\hline $51-69$ & 21 & 58 & 79 & & \\
\hline 70 or more & 1 & 5 & 6 & & \\
\hline
\end{tabular}


TABLE 4 - Continued

\begin{tabular}{|c|c|c|c|c|c|}
\hline \multirow[b]{2}{*}{ Variable } & \multicolumn{3}{|c|}{ Use iron cookware } & \multirow[b]{2}{*}{$d f$} & \multirow{2}{*}{$\begin{array}{l}\text { Chi- } \\
\text { square } \\
\text { value }\end{array}$} \\
\hline & No & Yes & Total & & \\
\hline & \multicolumn{3}{|c|}{ Number of subjects } & & \\
\hline \multicolumn{6}{|l|}{ Marital status } \\
\hline Married & 57 & 187 & 244 & 1 & $7.58 * *$ \\
\hline Single & 46 & 76 & 122 & & \\
\hline \multicolumn{6}{|l|}{ Ethnic group } \\
\hline Caucasian & 88 & 228 & 316 & 3 & 3.28 \\
\hline Hispanic & 6 & 18 & 24 & & \\
\hline Black & 3 & 11 & 14 & & \\
\hline Other & 6 & 6 & 12 & & \\
\hline \multicolumn{6}{|l|}{$\begin{array}{l}\text { Number in family that } \\
\text { you cook for }\end{array}$} \\
\hline 1 & 35 & 58 & 93 & 4 & 7.01 \\
\hline 2 & 27 & 75 & 102 & & \\
\hline 3 & 19 & 49 & 68 & & \\
\hline 4 & 14 & 45 & 59 & & \\
\hline 5 or more & 8 & 36 & 44 & & \\
\hline \multicolumn{6}{|l|}{ Occupation } \\
\hline Dietitian & 32 & 92 & 124 & 4 & $10.14 *$ \\
\hline Housewife & 12 & 41 & 53 & & \\
\hline Professor, teacher & 7 & 19 & 26 & & \\
\hline Student & 15 & 13 & 28 & & \\
\hline Other & 37 & 98 & 135 & & \\
\hline \multicolumn{6}{|l|}{ Education } \\
\hline Less than high school & 5 & 21 & 26 & 4 & 4.81 \\
\hline High school & 14 & 43 & 57 & & \\
\hline Some college & 20 & 45 & 65 & & \\
\hline Fin ished college & 43 & 84 & 127 & & \\
\hline Graduate study & 21 & 70 & 91 & & \\
\hline \multicolumn{6}{|l|}{ Education of spouse } \\
\hline Less than high school & 4 & 22 & 26 & 5 & $14.31 *$ \\
\hline High school & 8 & 43 & 51 & & \\
\hline Some college & 10 & 37 & 47 & & \\
\hline Finished college & 23 & 41 & 64 & & \\
\hline Graduate study & 13 & 43 & 56 & & \\
\hline No spouse & 45 & 77 & 122 & & \\
\hline
\end{tabular}


TABLE 4 - Continued

\begin{tabular}{|c|c|c|c|c|c|}
\hline \multirow[b]{2}{*}{ Variable } & \multicolumn{3}{|c|}{ Use iron cookware } & \multirow[b]{2}{*}{$\mathrm{df}$} & \multirow{2}{*}{$\begin{array}{l}\text { Chi- } \\
\text { square } \\
\text { value }\end{array}$} \\
\hline & No & Yes & Total & & \\
\hline & \multicolumn{3}{|c|}{ Number of subjects } & & \\
\hline \multicolumn{6}{|l|}{ Income } \\
\hline No answer & 16 & 34 & 50 & 5 & $14.19 *$ \\
\hline Less than $\$ 10,000$ & 10 & 7 & 17 & & \\
\hline$\$ 10,000-24,999$ & 21 & 85 & 106 & & \\
\hline$\$ 25,000-49,999$ & 35 & 95 & 130 & & \\
\hline$\$ 50,000-74,999$ & 15 & 35 & 50 & & \\
\hline$\$ 75,000$ or more & 6 & 7 & 13 & & \\
\hline
\end{tabular}

$* \mathrm{P}<0.05$.

$* * \mathrm{p}<0.01$. 
Chi-square analysis showed that the users of iron utensils versus nonusers of iron utensils was not independent $(P<0.05)$ of ownership of iron muffin pans, bacon cooked in iron utensils, age, occupation, education of spouse, and income. Also, the users of iron utensils versus the non-users was not independent $(5-0.01)$ of the following variables: own iron cookware, what the utensil used most often is made of, number of kinds of iron utensils owned, iron utensils owned (none, skillet, griddle, cornstick mold, and Dutch oven), frequency of use of iron skillet, frequency of use of iron utensils other than skillet, number of foods cooked in iron utensils, foods cooked in iron utensils (none, fried foods, cornbread, eggs, meat, other foods and all foods), change in use of iron utensils in the past 5 to 10 years, current use of iron utensils compared to use in the childhood home, and marital status. The major differences between the users and non-users of iron utensils for the discrete variables which were significant were the following. Almost all (99.6\%) of the subjects who used iron cookware owned it, although $26 \%$ of the subjects owned it but did not use it. Stainless steel or iron were about equally popular as the material of which the utensil used most often was made for the users of iron cookware $(33 \%$ and $31 \%$, respectively), while stainless steel was listed by the most non-users (44\%) and iron was listed by no non-users. More noniron users used aluminum (24\%) and other (25\%) cookware. Most of the users of iron utensils owned one (50\%) or two $(27 \%)$ kinds of iron utensils, while most of the non-users (75\%) owned no iron cuokware. All the users of iron cookware owned iron cookware, while $75 \%$ of the 
non-users owned no iron cookware. Most (95\%) of the users of iron cookware but only $22 \%$ of the non-users owned the iron skillet; $25 \%$ of the users of iron cookware but only $2 \%$ of the non-users owned the iron griddle; $24 \%$ of the users of iron cookware but only $6 \%$ of the non-users owned the iron cornstick mold; $26 \%$ of the users but only $4 \%$ of the non-users owned the iron Dutch oven; and $10 \%$ of the users but only $3 \%$ of the non-users owned the iron muffin pan. Most of the non-users of iron cookware (85\%) never used an iron skillet and the other $15 \%$ seldom used it, while most of the iron cookware users used an iron skillet several times a week $(34 \%)$ or daily $(32 \%)$. Most of the non-users of iron cookware (92\%) never used iron utensils other than the skillet, while only $41 \%$ of the iron cookware users never used iron utensils other than the skillet, $32 \%$ seldom used them, $9 \%$ used them every week, $12 \%$ used them several times weekly, and $7 \%$ used them daily. Most of the non-users of iron cookware (81\%) cooked no foods in iron utensils while most users of iron cookware cooked one (28\%), two (25\%), three $(18 \%)$, or all foods $(13 \%)$ in iron utensils. While $80 \%$ of the non-users of iron cookware and $2 \%$ of the users cooked no food in iron utensils, the following foods were listed as foods cooked in the iron utensils by more users than non-users of iron cookware: fried foods, cornbread, eggs, bacon, meat, other foods, and all foods. Although a large percentage of both the users (47\%) and non-users (43\%) of iron cookware indicated no change in the use of iron cookware in the past 5 to 10 years, more non-users (40\%) said their use was a lot less, while more users said their use was slightly more ( $8 \%$ ) or a lot more (12\%). 
Current use of iron cookware compared to use in childhood home was less for $85 \%$ of the non-users of iron cookware and for only $47 \%$ of the users, while $33 \%$ of the users said their use was the same and $21 \%$ said it was more. More non-users of iron cookware (13\%) than users (3\%) were in the age category of 19 to 22 years. More of the users of iron cookware $(71 \%)$ than the non-users $(55 \%)$ were married. More of the nonusers of iron cookware (15\%) than the users (5\%) were students. Education of spouse was greater for a larger percentage of the non-users than of the users of iron cookware. A greater percentage of non-users of iron cookware than of users had incomes in the lowest category of less than $\$ 10,000$ and in the highest category of $\$ 75,000$ or more, although a greater percentage of users than non-users had an income of $\$ 10,000-24,999$.

The number of iron utensils owned was obtained from the Fair sample only. Chi-square analysis, Table 5, indicated that the users of iron utensils versus the non-users of iron utensils was not independent $(P<0.01)$ of number of utensils owned. Most of the non-users of iron cookware (74\%) owned no iron cookware, while the respondents who used iron cookware owned two $(29 \%)$, three (20\%) or five or more (24\%) pieces of iron cookware. Analysis of variance showed a significant difference $(P<0.01)$ between the mean number of iron utensils owned by the non-users $(0.6)$ and users (3.7) of iron cookware.

Least squares means for the continuous socioeconomic variables and the use of iron cookware are shown in Table 6. Age, education, education of spouse, and income did not differ $(P<0.05)$. Only number in 
TABLE 5: Test for Independence for Use of Iron Cookware and the Number of Iron Utensils Owned

\begin{tabular}{|c|c|c|c|c|c|}
\hline \multirow[b]{2}{*}{ Variable } & \multicolumn{3}{|c|}{ Use iron cookware } & \multirow[b]{2}{*}{$\mathrm{df}$} & \multirow{2}{*}{$\begin{array}{l}\text { Chi- } \\
\text { square } \\
\text { value }\end{array}$} \\
\hline & No & Yes & Total & & \\
\hline \multicolumn{6}{|c|}{ Number of iron utensils owned } \\
\hline 0 & 36 & 0 & 36 & 5 & $126.13 * *$ \\
\hline 1 & 6 & 21 & 27 & & \\
\hline 2 & 5 & 38 & 43 & & \\
\hline 3 & 0 & 27 & 27 & & \\
\hline 4 & 1 & 15 & 16 & & \\
\hline 5 or more & 1 & 32 & 33 & & \\
\hline
\end{tabular}

$* * \mathrm{P}<0.01$ 


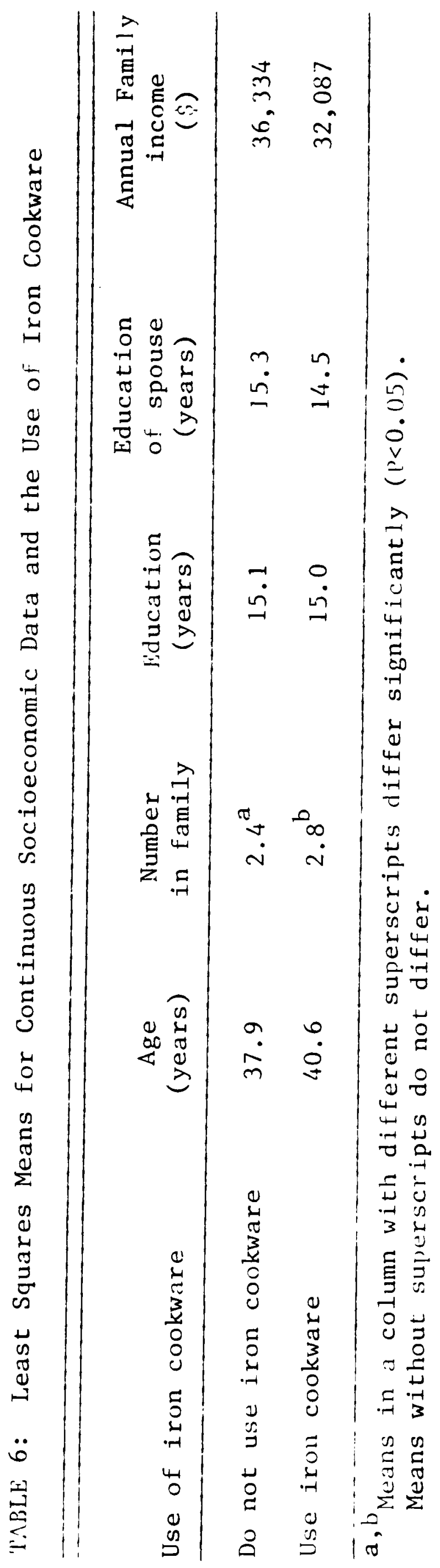


family differed $(P \div 0.01)$; non-users of iron cookware had a mean of 2.4 family members that they cook for, while users of iron cookware had 2.8 in the family.

The null hypothesis, there is no significant difference in the responses to the questions between subjects who use iron utensils and those who do not, was rejected for the variables that were not independent $(\mathrm{P}<0.05)$.

A comparison of the results of this research with the other published study on the use of iron cookware (White, 1968) shows many similarities. The present study reports results from 366 questionnaires; White reported results from 433 questionnaires. In the present study, $80 \%$ of the subjects indicated that they prepared most of their own meals, compared to $81 \%$ reported by White. In the present study, $75 \%$ of the subjects owned iron skillets, $20 \%$ owned a Dutch oven, $19 \%$ owned an iron griddle, $19 \%$ owned a cornstick mold, $8 \%$ owned an iron muffin pan and $7 \%$ owned other iron utensils; White reported that $71 \%$ owned iron skillets, $27 \%$ owned Dutch ovens, $18 \%$ owned iron griddles, $11 \%$ owned iron muffin pans and $14 \%$ owned other iron cookware, the most frequently mentioned was cornstick mold. In the present study, $15 \%$ of the subjects owned only one piece of iron cookware (usually a skillet), $24 \%$ owned two pieces, $15 \%$ owned three pieces, $9 \%$ owned four pieces, and $18 \%$ owned five or more; White's results were $36 \%, 26 \%, 10 \%, 4 \%$, and $1 \%$, respectively. White (1968) stated that $56 \%$ of all subjects who owned iron skillets used them frequently ( 2 or 3 times per week or every day); however, since only $71 \%$ of the subjects were owners, this meant that 
approximately $40 \%$ of all subjects might have an increase in dietary iron through frequent use of iron skillets in food preparation. Results are comparable in the present study: $48 \%$ of all subjects stated that they used iron skillets 2 or 3 times per week or every day.

In the present study, current use of iron cookware compared with use in childhood home is less for most of the subjects (58\%), the same for $27 \%$, and more for $15 \%$. Comparable figures reported by white (1968) are $62 \%, 16 \%$, and $6 \%$, respectively $(8 \%$ had no opinion and $8 \%$ did not answer the question).

In the present study, foods cooked in iron utensils were: none by $24 \%$ of the subjects, meat by $35 \%$, eggs by $19 \%$, fried foods by $17 \%$, cornbread by $10 \%$, al1 by $10 \%$, bacon by $7 \%$, and other foods by $34 \%$. Comparable figures reported by White were: no answer by $35 \%$ of the subjects, meat by about 33\%, eggs by $25 \%$, and other foods by 5 to $10 \%$.

In the present study, the type of cookware used most frequently was the skillet for $61 \%$ of the subjects and the saucepan for $30 \%$. More subjects indicated the most used utensil was made of stainless steel (36\%) than any other material; iron was the second most popular material with $22 \%$ of subjects stating that the most used utensil was made of iron. In the study by white (1968), aluminum, cast-iron and nonstick skillets were indicated with almost equal frequency and stainless steel skillets to a lesser degree as the utensil used most often and material it is made of. Iron utensils other than skillets were seldom or never used by $81 \%$ of the subjects in the present study; White reported that iron cookware other than skillets was seldom used 
by that sample. In both the present study and the study by White, $67 \%$ of the subjects were married.

\section{Iron in Food Study}

The design of the iron in food study was factorial: 20 foods $x$ 3 treatments (raw, cooked in the iron utensil, and cooked in the noniron utensil) $\times 2$ replications $\times 2$ samples. The effect of food, treatment, replication and sample on moisture and iron content is shown in Table 7. Moisture and iron content were significantly $(P<0.01)$ affected by food and treatment. It was expected that food would have a significant effect on moisture and iron content because some foods contain more moisture and iron than other foods. Moisture and iron content were not affected $(P<0.05)$ by replication or sample, due to careful preparation and analysis procedures.

Means for moisture and iron content of food by treatment are shown in Table 8. Moisture did not differ between food cooked in the iron utensil and food cooked in the non-iron utensil $(\mathrm{P}<0.05)$. Therefore, the difference in iron content of food cooked by the two methods is not related to difference in moisture content of food cooked by the two methods. Moisture was significantly $(P<0.01)$ higher for raw food than for food cooked by either method because moisture in food evaporates during cooking. Iron content of food conked in the iron utensil was more than twice the amount of food cooked in the non-iron utensil (mean $2.99 \mathrm{mg} / 100 \mathrm{~g}$ versus $1.18 \mathrm{mg} / 100 \mathrm{~g})(\mathrm{P}<0.01)$.

The means for moisture and iron content of the 20 foods by treatment are shown in Table 9. Most foods (12 out of 20) did not differ 
TABLE 7: Least Squares Analysis of Variance for the Effect of Food, Treatment, Replication and Sample on Moisture and Iron Content

\begin{tabular}{lccc}
\hline & & \multicolumn{2}{c}{ F value } \\
\cline { 3 - 4 } Source of Variation & df & Moisture & Iron \\
\hline Food & 19 & $323.58 * *$ & $11.73 *: \hbar$ \\
Treatment & 2 & $120.90 * *$ & $146.84 * *$ \\
Replication & 2 & 1.13 & 0.53 \\
Sample & 1 & 0.00 & 0.00 \\
Remainder & 335 & & \\
Total & 359 & & \\
\hline
\end{tabular}

$* * \mathrm{P}<0.01$; other values are not significantly different at 0.05 level. 
TABLE 8: Mean Moisture and Iron Content of Food by Treatment

\begin{tabular}{lcc}
\hline Treatment & $\begin{array}{c}\text { Moisture } \\
(\%)\end{array}$ & $\begin{array}{c}\text { Iron } \\
(\text { m } \vdots / 10.9 \mathrm{~g})\end{array}$ \\
\hline Raw & $70.29^{\mathrm{a}}$ & $0.99^{\mathrm{a}}$ \\
Cooked in iron utensil & $62.50^{\mathrm{b}}$ & $2.99^{\mathrm{b}}$ \\
Cooked in non-iron utensil & $62.49^{\mathrm{b}}$ & $1.18^{\mathrm{a}}$ \\
\hline
\end{tabular}

$a, b$ Means in a column with different superscripts differ $(P<0.01)$; ones with same superscript do not differ $(P<0.05)$. 
TABLE 9: Means for Moisture and Iron Content of 20 Foods by Treatment

\begin{tabular}{|c|c|c|c|c|c|c|}
\hline \multirow[b]{2}{*}{ Food } & \multicolumn{3}{|c|}{$\begin{array}{l}\text { Moisture } \\
(\%) \\
\end{array}$} & \multicolumn{3}{|c|}{$\begin{array}{c}\text { Iron } \\
(\mathrm{mg} / 100 \mathrm{~g}) \\
\end{array}$} \\
\hline & Raw & $\begin{array}{l}\text { Cooked } \\
\text { in iron } \\
\text { utensil }\end{array}$ & \begin{tabular}{l}
\multicolumn{1}{c}{ Cooked } \\
$\quad$ in \\
non-iron \\
utensil
\end{tabular} & Raw & $\begin{array}{l}\text { Cooked } \\
\text { in iron } \\
\text { utensil }\end{array}$ & $\begin{array}{c}\text { Cooked } \\
\text { in } \\
\text { non-irom } \\
\text { ltensil }\end{array}$ \\
\hline Stew & 87.06 & 82.80 & $81.31 *$ & 0.66 & 3.40 & $0.81 * \star$ \\
\hline Chili with meat & 78.31 & 71.55 & 72.27 & 0.98 & 6.27 & $1.28 * *$ \\
\hline $\begin{array}{l}\text { Spaghetti sauce } \\
\text { with meat }\end{array}$ & 82.63 & 78.94 & 78.78 & 0.71 & 3.58 & $0.94 * *$ \\
\hline Spaghetti sauce & 90.57 & 88.37 & $87.45 * *$ & 0.61 & 5.77 & $0.69 * 2$ \\
\hline Hamburger & 58.89 & 56.75 & $59.22 *$ & 1.49 & 2.29 & $2.00 * *$ \\
\hline Liver with onions & 75.37 & 63.16 & 63.15 & 3.10 & 3.87 & 3.82 \\
\hline Scrambled eggs & 76.63 & 69.48 & 69.54 & 1.49 & 4.76 & $1.79 * *$ \\
\hline Fried chicken & 66.83 & 52.18 & 52.10 & 0.88 & 1.89 & $1.37 * *$ \\
\hline Cornbread & 42.37 & 29.57 & $33.91 * *$ & 0.67 & 0.86 & 0.83 \\
\hline Pancakes & 54.32 & 46.89 & $46.40 *$ & 0.63 & 1.31 & $0.81 * *$ \\
\hline Rice & 60.42 & 59.62 & 60.46 & 0.67 & 1.97 & $0.86 * *$ \\
\hline Spanish rice & 67.56 & 68.62 & 68.52 & 0.87 & 2.25 & $0.83 * *$ \\
\hline Medium white sauce & 71.00 & 70.21 & 70.35 & 0.22 & 3.30 & $0.18 * *$ \\
\hline Fried egg & 75.11 & 71.25 & $69.66 * *$ & 1.92 & 3.48 & $1.84 * *$ \\
\hline Poached egg & 75.95 & 77.46 & 77.60 & 1.87 & 2.32 & $1.71 * *$ \\
\hline Bacon & 34.92 & 20.98 & 18.78 & 0.77 & 1.92 & $1.29 k *$ \\
\hline Fried Potatoes & 80.87 & 58.45 & 59.07 & 0.42 & 0.80 & $0.59 * *$ \\
\hline Green beans & 89.44 & 83.77 & 83.30 & 0.64 & 1.18 & $0.69 \% *$ \\
\hline Tortillas & 47.93 & 14.35 & $13.09 * *$ & 0.86 & 1.23 & $1.14 *$ \\
\hline Applesauce & 89.67 & 85.70 & $84.73 \div *$ & 0.35 & 7.38 & $0.28 \% *$ \\
\hline
\end{tabular}

* Means for cooked in iron and cooked in non-iron utensils differ $(\mathrm{P}<0.05)$.

**Means for cooked in iron and cooked in non-iron utensils differ $(\mathrm{P}<0.01)$. 
significantly $(\mathrm{F}<0.05)$ in moisture content when cooked in the two kinds of utensils. Most (18 out of 20) foods contained significantly $(p<0.05)$ more iron when cooked in the iron utensil than when cooked in the noniron utensil. The 18 foods which contained significantly $(P<0.05)$ more iron when cooked in iron than in non-iron utensils were: stew, chili with meat, spaghetti sauce with meat, spaghetti sauce, hamburger, scrambled eggs, fried chicken, pancakes, rice, Spanish rice, medium white sauce, fried egg, poached egg, bacon, fried potatoes, green beans, tortillas and applesauce. Ranked in descending order, according to the percent increase in iron content due to cooking in the iron utensil, the foods are: applesauce (2535\%), medium white sauce (1733\%), spaghetti sauce $(477 \%)$, chili with meat $(390 \%)$, stew $(320 \%)$, spaghetti sauce with meat $(281 \%)$, Spanish rice $(171 \%)$, scrambled eggs $(166 \%)$, rice $(129 \%)$, fried egg $(89 \%)$, green beans $(71 \%)$, pancakes $(62 \%)$, bacon $(49 \%)$, fried chicken (38\%), poached egg (36\%), fried potatoes (36\%), hamburger ( $15 \%)$, and tortillas $(8 \%)$.

Liver with onions and cornbread did not significantly $(\underline{p}<0.05)$ increase in iron content when cooked in the iron utensil. Burroughs and Chan (1972) reported a $17.6 \%$ increase in iron content of liver with onions when cooked in an iron skillet. Liver with onions had a significantly $(P<0.01)$ different iron content for replication. Variation of iron content within the liver with onions sample for each of the three replications probably was due to getting different amounts of liver and of onion in each sample and may be an explanation of why the liver with onions did not show a significant increase in iron when 
cooked in iron utensils. Moisture content of cornbread differed significantly $(\mathrm{P}<0.01)$ for cornbread cooked in the iron utensil and in the non-iron utensil; however, cornbread cooked in the non-iron utensil had lower iron content and higher moisture content. A possible explanation of why the cornbread cooked in the iron utensil did not contain more iron was that when the cornbread batter was poured into the hot skillet, a tough, dry crust immediately formed which was relatively impervious to taking up iron from the skillet. Most of the foods cooked in the non-iron utensil contain higher iron concentration than raw food due to moisture loss during cooking.

Iron content of most of the foods was slightly lower than the iron content listed in the Handbook No. 8 (USDA, 1963). White (1969) also reported lower analyzed iron values of foods than when calculated from food composition tables. The values for chicken corresponded closely with the values reported by Meiners et al. (1982). Overall, most iron content values of foods were lower for the foods that were also analyzed by previous researchers Moore (1965) and Burroughs and Chan (1972). The iron content value of the Spanish rice was higher than the iron content value for Spanish rice listed in Handbook No. 8 (USDA, 1963) or reported by Burroughs and Chan (1972). Iron content value for scrambled eggs was also higher than the value listed in Handbook No. 8 (USDA, 1963) and the iron content value reported by Moore (1965). Nutrient values in food composition tables are averages, indicating nutrients contributed by a food on a year-round, country-wide basis. Therefore, analyzed values of foods consumed at a specific time and location would 
not necessarily be expected to agree with food tables (White, 1969). Means for $\mathrm{pH}$ of the raw food, cooking time and moisture content are shown in Table 10. Several researchers have suggested that foods which contain more moisture, are more acidic (Mackay et al., 1945; Moore, 1965; Monsen et al., 1967; Burroughs and Chan, 1972) and are cooked longer times (Moore, 1965; Burroughs and Chan, 1972), take up more iron when cooked in iron utensils. In the present study, the food which increased in iron content most when cooked in iron utensil was applesauce. Applesauce was the food with the lowest $\mathrm{pH}$ and next to the highest moisture content; however, its cooking time was intermediate (20 minutes). Medium white sauce was the food which increased next most in iron content when cooked in iron utensil; medium white sauce did not have a low $\mathrm{pH}$, high moisture content or long cooking time. Stew had the longest cooking time and relatively low $\mathrm{pH}$ and high moisture content; it increased $320 \%$ in iron content during cooking in iron utensil.

To determine whether iron content of food was associated with $\mathrm{pH}$ of raw food, cooking time, or moisture content of food correlation coefficients were determined for iron content, $\mathrm{pH}$ of the raw food, cooking time, and moisture of foods cooked in iron and in non-iron utensils. The correlation coefficient of iron content with $\mathrm{pH}$ of the raw food was low $(-0.22)$, although highly significant $(P<0.01)$. The correlation coefficient of iron content with cooking time was low $(0.14)$, although significant $(?<0.05)$. The correlation coefficient of iron content with moisture content was low (0.29), although highly 
TABLE 10: Means for pH, Cooking Time and Moisture Content of 20 Foods

\begin{tabular}{|c|c|c|c|}
\hline Food & $\mathrm{pH}$ & $\begin{array}{l}\text { Cooking } \\
\text { time } \\
\text { (min) }\end{array}$ & $\begin{array}{c}\text { Moisture } \\
(\%)\end{array}$ \\
\hline Stew & 5.44 & 77.0 & 83.72 \\
\hline Chili with meat & 5.27 & 36.0 & 74.04 \\
\hline Spaghetti sauce with meat & 5.03 & 34.0 & 80.11 \\
\hline Spaghetti sauce & 4.50 & 23.0 & 88.80 \\
\hline Hamburger & 5.77 & 9.0 & 58.27 \\
\hline Liver with onions & 6.10 & 11.0 & 67.25 \\
\hline Scrambled eggs & 7.20 & 4.0 & 71.88 \\
\hline Fried chicken & 6.15 & 17.5 & 57.04 \\
\hline Cornbread & 6.81 & 15.0 & 35.29 \\
\hline Pancakes & 6.71 & 3.3 & 49.21 \\
\hline Rice & 6.22 & 20.0 & 60.16 \\
\hline Spanish rice & 4.61 & 27.0 & 68.23 \\
\hline Medium white sauce & 6.48 & 12.0 & 70.52 \\
\hline Fried egg & 7.33 & 6.0 & 72.00 \\
\hline Poached egg & 7.58 & 5.0 & 77.00 \\
\hline Bacon & 6.37 & 5.0 & 24.89 \\
\hline Fried potatoes & 5.94 & 3.0 & 66.13 \\
\hline Green beans & 6.09 & 5.0 & 85.51 \\
\hline Tortillas & 9.34 & 1.0 & 25.12 \\
\hline Applesauce & 3.90 & 20.0 & 86.70 \\
\hline
\end{tabular}


significant $(P<0.01)$. Therefore, higher iron content was significantly associated with lower $\mathrm{pH}$ (more acidic), longer cooking time, and more moisture, indicating that more acidic, more moist, and longer cooked foods may take up more iron during cooking in iron utensils.

In another correlation analysis, correlation coefficients were determined for the increase in iron content with $\mathrm{pH}$ of the raw food, cooking time, and moisture content of the raw food. Increase in iron content was the difference between iron content of food cooked in iron utensil and in non-iron utensil. The correlation coefficients were $-0.58,0.39$, and 0.55 , respectively, and were highly significant $(\mathrm{P}<0.01)$. The amount of variation $\left(\mathrm{r}^{2}\right)$ in increase in iron content of food cooked in iron utensil over that of food cooked in the non-iron utensil accounted for by each factor was $0.34,0.15$, and 0.30 , respectively, making a total of 0.79 , or $79 \%$, of the variation accounted for by all three factors. Thus, this analysis showed that the increase in iron content by cooking in the iron utensil was signficiantly associated with acidity and moisture content of raw food and with cooking time, indicating that more acidic, moister, and longer cooked foods take up more iron during cooking in iron utensils.

The effect of food, treatment, replication and sample on the moisture and iron content of three foods cooked in two different iron skillets is shown in Table 11. Food and treatment (cooked in iron skillet $A$ or cooked in iron skillet $B)$ affected $(\mathrm{P}<0.01)$ iron content while only food affected $(P<0.01)$ moisture content. Replication affected $(\mathrm{P}<0.01)$ moisture, indicating variability among replications. 
TABLE 11: Least Squares Analysis of Variance for the Effect of Food, Treatment, Replication and Sample on the Moisture and Iron Content of Three Foods Cooked in Two Iron Utensils

\begin{tabular}{lccc}
\hline & & F values \\
\cline { 3 - 4 } Source of variation & 2 & Moisture & Iron content \\
\hline Food & 1 & 1.20 & $23.42 * *$ \\
Treatment & 2 & $6.01 * *$ & $13.13^{* * *}$ \\
Replication & 1 & 0.04 & 0.00 \\
Sample & 1.86 &
\end{tabular}

$* * P<0 . C_{i}$; other values non-significant at 0.05 level. 
Replication did not significantly affect iron content. Sample did not affect moisture or iron content, indicating careful control in analysis procedures.

Table 12 shows the means for moisture and iron content of the three foods by treatment. Moisture content was not different $(P<0.05)$ between food cooked in iron utensil A and food cooked in iron utensil B. Iron content of food cooked in iron utensil B was approximately $154 \%$ of iron content of food cooked in iron utensil A (mean 9.20 versus $5.97 \mathrm{mg} / 100 \mathrm{~g}$ ), a difference which was highly significant $(\mathrm{P}<0.01)$. Iron utensil $\mathrm{B}$ was like iron utensil A except iron utensil A had been used more. Both had been obtained new for this research. Skillet A had been used daily for a week before this research began, while skillet $B$ had been used only two or three times prior to the study. Also, during the study, skillet A was used for all 20 foods and skillet B was used for only three foods. The three foods were cooked in this order in the total 20 foods: 4, 7, and 20; for spaghetti sauce, scrambled eggs and applesauce, respectively.

The mean iron content of the three foods cooked in two iron utensils is shown in Table 13. Of the three foods cooked in two different iron skillets, only one had a signficantly different iron content. Applesauce contained significantly $(\mathrm{P}<0.01)$ more iron (more than twice as much) when cooked in iron skillet B than iron skillet A. Thus, some variation in iron content of food uccurred due to using different iron skillets. Iron content of spaghetti sauce cooked in iron utensil A did not differ significantly from iron content of 
TABLE 12: Mean Moisture and Iron Content of Three Foods by Treatment

\begin{tabular}{lcc}
\hline Treatment & $\begin{array}{c}\text { Moisture } \\
(\%)\end{array}$ & $\begin{array}{c}\text { Iron } \\
(\mathrm{mg} / \mathrm{l00g})\end{array}$ \\
\hline Cooked in iron utensil A & 81.18 & $5.97 * *$ \\
Cooked in iron utensil B & 80.69 & 9.20 \\
\hline
\end{tabular}

**Means in column differ $(\mathrm{P}<0.01)$; means in other column do not differ $(\mathrm{P}<0.05)$. 
TABLE 13: Mean Iron Content of Three Foods Cooked in Two Iron Utensils

\begin{tabular}{lcc}
\hline & \multicolumn{2}{c}{$\begin{array}{c}\text { Iron } \\
(\mathrm{mg} / 100 \mathrm{~g})\end{array}$} \\
\cline { 2 - 3 } Food & $\begin{array}{c}\text { Cooked in } \\
\text { iron utensil A }\end{array}$ & $\begin{array}{c}\text { Cooked in } \\
\text { iron utensil B }\end{array}$ \\
\hline Scrambled eggs & 5.77 & 5.84 \\
Applesauce & 4.76 & 5.38 \\
\hline
\end{tabular}

$* * P<0.01 ;$ other differences are non-significant at 0.05 level. 
spaghetti sauce cooked in iron utensil B; the same was true for scrambled eggs. 
CHAPTER IV

SUMMARY AND CONCLUSIONS

A survey on the current use and change in use of iron cooking utensils was obtained from 366 respondents at a fair and a national convention. Seventy-nine percent of the subjects owned iron utensils. Seventy-two percent of the subjects used iron cookware. The kind of iron utensil owned by the most people (75\%) was the skillet. Almost one-half $(48 \%)$ of the subjects said they used the iron skillet daily or several times per week. Foods cooked in iron utensils included meat, eggs, fried foods, cornbread and bacon.

Regarding change in use of iron cookware during the past five to ten years, more subjects $(46 \%)$ indicated no change than any other response, although $24 \%$ said they presently used iron cookware a lot less and $9 \%$ said they used iron cookware at lot more. of the $50 \%$ of the subjects who own a microwave oven, $62 \%$ said their use of iron cookware is the same since acquiring the microwave oven and $37 \%$ said their use of iron cookware is less. Fifty-five percent of the respondents reported that their use of iron utensils is less than in their childhood home.

In the analysis of the Fair sample versus the Convention sample, most variables related to cooking did not differ significantly for the two samples. However, all of the socioeconomic variables differed significantly for the two samples. The results of the present survey on the use of iron cookware are very similar to those reported by 
White over fifteen years ago.

Twenty foods were cooked in iron and non-iron utensils to determine iron content of food due to cooking in iron utensils. Eighteen out of the 20 foods contained significantly $(\mathrm{P}<0.01)$ more iron when cooked in the iron utensil than when cooked in the non-iron utensil. Food cooked in the iron utensil contained an average of two and onehalf times as much iron as food cooked in the non-iron utensil. The greatest increase in iron was in applesauce. Moisture content and p! of raw food and cooking time were significantly $(P<0.01)$ correlated to increased iron content of food cooked in the iron utensil, indicating that foods with more moisture, more acidity and longer cooking time take up more iron from iron cookware.

There was some variation in iron content of the three foods cooked in the two different iron skillets. Of the three foods cooked in two different iron skillets, only one had a significantly different. iron content.

In conclusion, iron utensils can be used to significantly increase the amount of dietary iron. Nutrition education regarding the increase in dietary iron possible from cooking in iron utensils is needed, especially for persons at risk of iron deficiency. Also, care should be taken when calculating iron content of diets to include iron from cooking utensils when food is cooked in iron cookware. The added iron in food from cooking in iron utensils is of greater significance now because recent research has shown that enhancing factors of ascorbic acid and meat, fish and poultry increase absorption of non-heme iron. 
More research is needed on the bioavailability of the added iron and the effect of the added iron on nutritional status. 


\section{REFERENCES}

AOAC, 1980. "Official Methods of Analysis." 13th ed. Association of Official Analytical Chemists, Washington, D.C.

Beutler, E. 1980. Iron. In Goodhart, R. S. and Shils, M. E., eds. "Modern Nutrition in Health and Disease." 6th ed. Lea and Febiger, Philadelphia.

Bothwe11, T. H., Seftel, H., Jacobs, P., Torrance, J. D., and Baumslag, N. 1964. Iron overload in Bantu subjects: studies in the availability of iron in Bantu beer. Am. J. Clin. Nutr. 14:47.

Brittin, H. C. and Zinn, D. W. 1977. Meat-buying practices of Caucasians, Mexican-Americans and Negroes. J. Amer. Dietet. Assoc. $71: 623$.

Burroughs, A. L. and Chan, J. 1972. Iron content of some MexicanAmerican foods. J. Amer. Dietet. Assoc. 60:123.

Drover, D. P. and Maddocks, I. 1975. Iron content of native foods. Papua New Guinea Medical Journal. 18:15.

Food and Nutrition Board, 1980. Recommended Dietary Allowance. 9th rev. ed. Washington, D.C.: Nat'l Acad. Sci.

Harvey, W. R. 1960. Least squares analysis of data with unequal subclass number. USDA ARS Bul1. 20-8, Government Printing Office, Washington, D.C.

Lal, H., Agarwal, K. M., Gupta, M. and Agarwal, D. K. 1973. Protein and iron supplementations by altering cooking practices in a community. Indian Journal of Medical Research. 61:918.

Mackay, H. M., Dobbs, R. H. and Bingham, K. 1945. The effect of national bread, of iron medicated bread, and of iron cooking utensils on the hemoglobin level of children in wartime day nurseries. Arch. Dis. Childh. 20:56.

Meiners, C., Crews, M. G. and Ritchy, S. J. 1982. Yield of chicken parts: proximate composition of mineral content. J. Amer. Dletet. Assoc. $77: 258$.

Mertz, W. 1980. Mineral elements: new perspectives. J. Amer. Dietet. Assoc. $77: 258$. 
Monsen, E. R., Kuhn, I. N. and Finch, C. A. 1967. Iron status of menstruating women. Amer. J. Clin. Nutr. 20:342.

Monsen, E. R., Hallberg, L., Layrisse, M., Hegsted, D. M., Cook, J. D., Mertz, W., and Finch, C. A. 1978. Estimation of Available Dietary Iron. Amer. J. Clin. Nutr. 31:134.

Monsen, E. R. and Balintfy, J. L. :982. Calculating dietary iron bioavailability: refinement and computerization. J. Amer. Dietet. Assoc. 80:307. Moore, C. V. 1965. Iron nutrition and requirements. Series Haema-
tology. $6: 1$.

Nie, N. H., Hul1, C. H., Jenkins, J. G., Steinbrenner, K. and Bent, D. H. 1975. Statistical Package for the Social Sciences. McGraw-Hill Book Company, New York.

Perkin-Elmer. 1980. "Analytical Methods for 5000 Atomic Absorption Spectrophotometry." Perkin-Elmer Co., Norwalk, Connecticut.

Pomeranz, Y. and Meloan, C. E. 1978. "Food Analysis: Theory and Practice." AVI Publishing Company, Inc., Westport, Connecticut.

Robinson, C. H. and Lawler, M. R. 1982. Mineral Elements. "In Normal and Therapeutic Nutrition." 16th ed. MacMillan Publishing Co., Inc., New York.

Seiler, H., Schlettwein-Gsell, D., Brubacher, G., and Ritzel, G. 1977. The mineral content of meat depending on the method of preparation. Mitteilungen aus dem Gebiete der Lebensmitteluntersuchung und Hygiene. $68: 523$.

United States Department of Agriculture. 1963. Handbook No. 8. Composition of Foods. Washington, D.C.

United States Department of Agriculture. 1976-1982. Handbook No. 8-1 - 8-9. Composition of Foods. Washington, D.C.

White, H. S. 1968. Current use and changes in use of cast-iron cookware. Journal of Home Economics. 60:724.

White, H. S. 1969. Inorganic elements in weighed diets of girls and young women. J. Amer. Dietet. Assoc. 55:38. 
APPENDIX
A. QUESTIONNAIRE ON USE OF IRON COOKWARE, FAIR
B. QUESTIONNAIRE ON USE OF IRON COOKWARE, CONVENTION
C. RECIPES
D. FOOD COOKING RECORD 
Sex: Male Female

Ethnic group: A. Caucasian

C. Black

B. Mexican-American

D. Other

1. Do you prepare most of your own meals? Yes

2. Do you own cast-iron cookware? Yes No

3. Which cast-iron cookware do you own?
skillet
griddle
Dutch oven
muffin pans
corn-stick molds other ( 1 ist)

4. How many pieces of cast-iron cookware do you own?

5. How often do you use cast-iron skillets? every day

2 or 3 times per week

2 or 3 times per month

seldom

Never

6. How often do you use cast-iron utensils other than the skillet? every day

2 or 3 times per week seldom every week

never

7. What foods do you cook in cast-iron utensils? In skillet In other

8. How has your use of cast-iron utensils changed during the past 5 to 10 years?

No change Use a lot more Use slightly more

Use slightly less

Use a lot less

9. What is your current use of cast-iron cookware compared with that in your childhood home? No change Less More

10. a. What kind of utensil do you use most often? skillet or? b. What is it made of?

11. Do you own and use a microwave oven? Yes

No

12. Have you changed your use of iron cooking utensils since you got a microwave? No change Use less Use more

13. Are you married or single? Married Single

14. How many people are in your family? (that you cook for)

15. How old are you?

16. How many years of school and college have you completed?

17. How many years of school and college has your husband completed?

18. Your occupation?

19. What is your annual family income? 
APPENDIX B: QUESTIONNAIRE ON USE OF IRON COOKWARE, CONVENTION TEXAS TECH UNIVERSITY, DEPARTMENT OF FOOD AND NUTRITION

Please check the appropriate answer or fill in the blank.

1. What proportion of your meals do you prepare?

None Less than half
Half More than half

2. A. Which utensil do you use most often?

Skillet Dutchoven Other (list)

B. What is it made of?

Aluminum
Cast-iron
Other (identify) Corningware

3. Do you use cast-iron cookware?

4. Which cast-iron cookware do you own? Yes No

Skillet Griddle Cornstick molds $\overline{0 \text { ther (list) }}$

5. How often do you use cast-iron skillets?

Every day
2 or 3 times per week
2 or 3 times per $\frac{\text { month }}{\text { Sever }}$

6. How often do you use cast-iron utensils other than skillets?

Saucepan Roaster

Every day
2 or 3 times per week
2 or 3 times per $\frac{\text { month }}{2}$
Seldom

7. Which foods do you cook in cast-iron utensils?

8. How has your use of cast-iron utensils changed during the past 5 to 10 years? _Same _Lot more _Slightly more Slightly less _Lot less

9. What is your current use of cast-iron cookware compared with that in your childhood home?

Same Less More

10. Do you own and use a microwave oven? Y Yes No

11. How has your use of iron cooking utensils changed since you got a microwave? Same Use less Use more

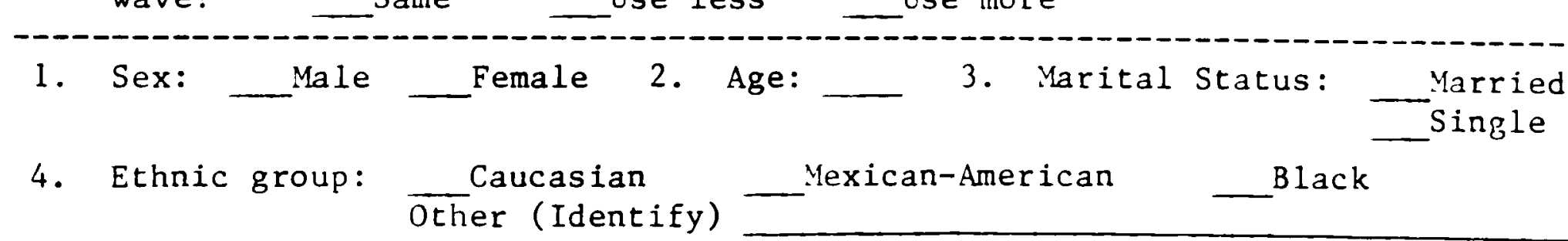

5. Number of people in your family that you cook for:

6. Occupation:

7. State of residence:

8. Highest education completed: High school Years of college $1 \quad 2 \quad 3 \quad 4$ Masters degree Doctorā dégrēe

9. Education completed by spouse:

10. Annual family income before taxes: \$

Comments about iron cookware: 
APPENDIX C: RECIPES

\section{Scrambled Eggs}

\section{(4 $X 1$ serving)}

$\begin{array}{rll}209.4 \mathrm{~g} & 4 \text { large eggs } \\ 58.6 \mathrm{~g} & 1 / 4 \text { cup milk }\end{array}$

$$
\begin{array}{rll}
4.0 \mathrm{~g} & 1 / 2 \text { teaspoon salt } \\
12.5 \mathrm{~g} & 1 \text { tablespoon oil }
\end{array}
$$

Weigh and record weight of all ingredients. Mix eggs, milk, and salt with a fork. Divide into fourths, weighing and recording each portion and placing one fourth in one of four custard cups labeled raw, iron, Corning, and iron $B$.

Record time. Pour one fourth into hot greased (1 teaspoon $4.1 \mathrm{~g}$ oil) iron skillet, one fourth into hot greased (1 teaspoon $4.1 \mathrm{~g}$ oil) Corning dish, and one fourth into hot greased ( 1 teaspoon $4.1 \mathrm{~g}$ oil) iron skillet $B$.

Cook over low heat, stirring occasionally with egg turner while cooking. Record time and total cooking time. Weigh and record weight of each cooked fourth. Blend each of the four fourths. Take pH and record. Place each fourth in a plastic bag, label, and freeze.

\section{Pan-broiled Hamburger Patties}

\section{(3 $\times 1$ serving)}

\section{$340.5 \mathrm{~g} \quad 3 / 4$ pound ground beef $\quad 5.1 \mathrm{~g} \quad 3 / 4$ teaspoon salt}

Weigh and record weight of each ingredient. Mix beef and salt. Shape into three patties about $1 / 2$ inch thick and of equal weight, weighing and recording weight of each. Record time. Cook one in iron skillet and one in Corning dish on medium-high then medium heat about 5 minutes on one side, pour off drippings (and save), turn and cook on other side about 4 minutes until medium done (brown on outside and pink in inside). Save drippings and label each for later use with gravy. Weigh and record weight of each of the two cooked patties. Blend each of the three patties; take $\mathrm{pH}$ of each and record; place each in a plastic bag, label, and freeze. 
3. Spaghetti Sauce

$$
\text { (4 } \times 4 \text { servings) }
$$

\footnotetext{
$174.0 \mathrm{~g} \quad 41.5 \mathrm{oz}, 42 \mathrm{~g}$ packages Schilling spaghetti sauce mix $893.6 \mathrm{~g} \quad 48 \mathrm{oz}$ cans tomato sauce $1422.0 \mathrm{ml} 41 \frac{1}{2}$ cans deionized water
}

Weight each ingredient and record weight. Divide each ingredient into fourths, weighing and recording weight of each fourth.

Put one fourth into iron skillet; put one fourth into Corning dish; and put one fourth into iron skillet B. Record time. Heat each fourth over medium high heat and simmer on low heat for 20 minutes. Record end of cooking time and total cooking time.

Weigh and record weight of each of the three cooked fourths. Blend each of the four fourths. Take $\mathrm{pH}$ of each fourth and record. Place each fourth in a plastic bag, label, and freeze.

\section{Spaglett i Sauce with Meat}

$130.5 \mathrm{~g} \quad 31.5 \mathrm{oz}, 42 \mathrm{~g}$ packages Schilling spaghetti sauce mix $670.3 \mathrm{~g} \quad 38$ oz cans tomato sauce
$1066.5 \mathrm{ml} 31 \frac{1}{2}$ cans deionized water

$681.0 \mathrm{~g} \quad 1 \frac{1}{2} 1 \mathrm{~b}$ ground beef

Weigh each ingredient and record weight. Divide each ingredient into thirds, weighing and recording weight of each third of each ingredient and placing one third of each ingredient on one of three waxed paperlined trays labeled raw, iron and Corning.

Combine the one third of each ingredient on raw tray, weigh and save for raw sample.

Record time. Brown the one third of the ground beef on the iron tray in iron skillet and the one third of the ground beef on the Corning tray in Corning dish on medium heat. Stir one third of the spaghetti sauce mix, tomato sauce and one third of the water on the iron tray into the browned beef in the iron skillet; stir the one third of the spaghetti sauce mix, tomato sauce and one third of the water on the Corning tray into the browned beef in the Corning dish. Heat each of the two thirds over medium high meat and simmer 20 minutes. Record time and total cooking time. Weigh and record weight of each cooked third.

Blend each of the three thirds; take $\mathrm{pH}$ of each and record; and place each third in a plastic bag, label and freeze. 
5. Chili (Beans and Meat)

\section{(3 $\times 4$ servings)}

$\begin{array}{rl}454.0 \mathrm{~g} & 1 \text { pound dried pinto beans } \\ 908.0 \mathrm{ml} & 4 \text { cups deionized water } \\ 1362.0 \mathrm{~g} & 3 \text { pounds ground beef } \\ 5.7 \mathrm{~g} & 3 \text { cloves garlic }\end{array}$

$454.0 \mathrm{~g} \quad 1$ pound dried pinto beans

$908.0 \mathrm{ml} 4$ cups deionized water

$5.7 \mathrm{~g} 3$ cloves garlic

$\begin{array}{rll}346.8 \mathrm{~g} & 3 \text { medium onions } \\ 19.2 \mathrm{~g} & 1 \text { tablespoon salt } \\ 7.8 \mathrm{~g} & 1 \text { tablespoon chili } \\ & & \text { powder } \\ 1362.0 \mathrm{~g} & 3 \mathrm{l} 1 \mathrm{~b} \text { cans tomatoes }\end{array}$

Pick out dirt balls and defective beans and discard. Weigh and record weight of beans and $\mathrm{ml}$ of deionized water. Wash beans with cold water. Divide beans into thirds, weighing and recording weight of each.

Place one third in plastic bag, one third in iron skillet, and one third in Corning dish. Divide water into thirds, measuring and recording $\mathrm{ml}$. of each. Add equal amounts of water to each third of beans. Bring water in iron skillet and in Corning dish to boiling, turn off heat, cover, and let beans soak overnight.

Next day: divide each third of beans and soaking water (weigh and record) into three thirds, one for each replication and put on the rep trays. Record time. In the utensils they were soaked in, bring the beans with soaking water to boiling over high heat, add $100 \mathrm{ml}$ deionized water to each skillet (to cover beans), reduce heat to low, cover and simmer 20 minutes until beans are tender.

Peel and mince garlic. Peel and chop onion. Weigh and record weight of beef, garlic, onion, salt, chili powder, and tomatoes. Divide each ingredient into thirds, weighing and recording each third of each ingredient, and placing one third of each ingredient on a tray labeled raw, iron, or Corning.

Add one third of the ingredients (those on the raw tray) to the raw beans and water in the plastic bag. Weigh and record weight.

When the beans have simmered in the iron skillet and Corning dish until they are tender, pour them up and set them aside. Brown one third of the beef in the iron skillet; brown one third of the beef in the Corning dish over medium heat. Put one third of garlic and onion in iron skillet; put one third of garlic and iron in Corning dish. Cook the mixture in iron skillet and cook mixture in Corning dish over medium high heat until garlic and onion are transparent. Add one third of the salt, chili powder, and tomatoes to the mixture in the iron skillet; add one third of the salt, chili powder and tomatoes to the mixture in the Corning dish. Stir the one third of the beans with liquid which were cooked in the iron skillet into the mixture in the iron skillet; stir the one third of the beans with liquid which were cooked in the Corning dish into the mixture in the Corning dish. Bring mixture in iron skillet and mixture in Corning dish to boiling over high heat, cover and simmer 15 minutes. Record time and total cooking time.

Weigh and record the weight of the mixture cooked in the iron skillet; weigh and record the weight of the mixture cooked in the Corning dish. Blend each of the three thirds; take $\mathrm{pH}$ of each and record; place each third in a plastic bag, label and freeze. 


\title{
6. Applesauce
}

\section{(4 $\mathrm{X} 4$ servings)}

\author{
$1036.8 \mathrm{~g} \quad 12$ medium apples \\ $118.0 \mathrm{ml}$ 's cup water
}

Remove blossom and stem end of apples. Cut apples into eighths. Weigh and record weight of apples. Divide apple slices into four portions of equal weight (weigh and record each). Save one fourth raw. Add $1 / 4$ of water (measure in $\mathrm{ml}$ and record) to each fourth of apple slices. Weigh and record each fourth of apple slices with water. Put one fourth of apple slices and water in iron skillet; put one fourth of apple slices and water in Corning dish; and put one fourth of apple slices and water in iron skillet $B$; record time; bring water to boiling on high heat, reduce heat and simmer, covered, 20 minutes (until slices are very tender when pierced with a fork). Record time and cooking time. Weigh and record weight of each cooked fourth.

Force each cooked fourth through a colander to remove seeds and peelings, rinsing the colander and mallet with deionized water twice between measuring each fourth.

Blend each of the four fourths; take $\mathrm{pH}$ of each and record; place each fourth in a plastic bag, label and freeze.

\section{Bacon}

\section{( 3 X 2 slices)}

\section{$96.4 \mathrm{~g} 6$ slices bacon}

Weigh bacon and record weight. Divide bacon into 3 sets of 2 slices each; weigh and record.

Record time. Cook 2 slices of bacon in iron skillet on medium heat and cook 2 slices in Corning dish to the same doneness. When done on one side, pour off fat (and label and save for use in stir fried green beans), turn and cook on other side. Record time and cooking time.

Weigh and record weight of each set of slices cooked. Blend each of the three thirds; take $\mathrm{pH}$ and record; place each third in a plastic bag, label and freeze. 
8. Cornbread

( 3 X 1 layer)

$225.0 \mathrm{~g} \quad 1 \frac{1}{2}$ cup cornmeal

$172.5 \mathrm{~g} \quad 1 \frac{1}{2}$ cup flour

$19.5 \mathrm{~g} l$ tablespoon + $1 \frac{1}{2}$ teaspoon baking powder

$9.9 \mathrm{~g} \quad 1^{\frac{1}{2}}$ teaspoon salt

$$
\begin{array}{rll}
37.5 & \mathrm{~g} & 3 \text { tablespoon sugar } \\
76.0 & \mathrm{~g} & 6 \text { tablespoon oil } \\
351.2 & \mathrm{~g} & \mathrm{l} \frac{1}{2} \text { cup milk } \\
75.0 \mathrm{~g} & 1 \frac{1}{2} \text { egg }
\end{array}
$$

Oil (with $4.2 \mathrm{~g} 1 \mathrm{tsp}$ oil) and heat irou skillet; oil (with $4.2 \mathrm{~g} 1$ tsp oil) and heat Corning dish in oven. Weigh and record weight of each ingredient. Sift dry ingredients together in bowl. Combine liquid ingredients and stir with a fork to mix. Add liquid to dry ingredients. Stir just enough to dampen dry ingredients (about 15 strokes).

Divide batter into thirds, weighing and recording weight of each. Save one third raw. Fill greased and heated iron skillet with one third; fill oiled and heated Corning dish with one third. Bake at $425^{\circ} \mathrm{F} 15$ minutes. Record time and cooking time. Weigh each of the two cooked layers and record weight.

Blend each of the three thirds; take $\mathrm{pH}$ and record; place each third in a plastic bag, label and freeze.

\section{French Fried Potatoes}

(3 X 1 potato)

$312.0 \mathrm{~g} \quad 3$ medium potatoes, peeled $200 \mathrm{~g} \quad 1$ cup oil

Peel and slice potatoes. Weigh and record weight of potatoes. Divide into thirds, weighing and recording weight of each third. Weigh and record weight of oil. Divide oil in halves, weigh and record weight of each half, and put half of oil into iron skillet and half into Corning dish. Heat oil to hot $\left(350^{\circ} \mathrm{F}\right)$ on high. Record time. Cook one third of the potatoes in iron skillet and one third in Corning dish for the same time to the same doneness, stirring occasionally so potatoes brown evenly. Record time and cooking time. Drain each third of potatoes on paper towel. Weigh and record weight of each cooked third.

Blend each of the three thirds; take $\mathrm{pH}$ of each and record; place each third in a plastic bag, label and freeze. 
10. Spanish Rice

( $3 \times 1$ cup rice -4 servings)

$585.0 \mathrm{~g} \quad 3$ cup rice

$75.0 \mathrm{~g} \quad 6$ tablespoons oil

$274.5 \mathrm{~g} \quad 3$ medium onions, peeled

$18.6 \mathrm{~g} 3$ green onions
$681.0 \mathrm{~g} \quad 3$ cup canned tomatoes

$711.0 \mathrm{ml} 3$ cup deionized water

$9.9 \mathrm{~g} \quad 1 \frac{1}{2}$ teaspoons salt

$2.7 \mathrm{~g} 1$ teaspoon chili powder

Weigh and record weight of each ingredient. Divide each ingredient into thirds, weighing and recording weight of each third of each ingredient. Combine one third of each of the ingredients; weigh and record weight; and save for raw. Chop onions.

With one third of the ingredients: record time; saute rice in oil over medium high until lightly browned; add remaining ingredients, stir, cover and simmer on low heat in iron skillet until rice is tender $(20$ minutes); record time and cooking time. With other third of the ingredients: Cook same as above except in a Corning dish. Weigh each of the two cooked thirds and record weight.

Blend each of the three thirds; take $\mathrm{pH}$ of each and record; and place each third in a plastic bag, label and freeze.

\section{Stir-Fried Green Beans}

\section{( $3 \times 4$ servings)}

$762.0 \mathrm{~g} \quad 39 \mathrm{oz}$ packages frozen French-style green beans

$41.2 \mathrm{~g} \quad \frac{1}{4}$ cup bacon drippings (from cooking bacon)

$5.1 \mathrm{~g} \quad 3 / 4$ teaspoon salt

Weigh and record weight of each ingredient. Divide all ingredients except drippings into three equal amounts, weighing and recording each. Combine one third of each of the ingredients; weigh and record; and save for raw.

Record time. Heat over medium high one-half of the bacon drippings (weigh and record weight) in iron skillet; heat the other half of the drippings in Corning dish. Add one third of beans to iron skillet; add one third of beans to Corning dish. Toss beans around with egg turner to coat beans with drippings. Add one third of salt to iron skillet; add one third of salt to Corning dish. Cover tightly and simmer over low heat until beans are tender, 5 minutes. Record time and cooking time. Weigh each of the two cooked thirds and record weight of each.

Blend each of the three thirds; take pH of each third and record; place each third in a plastic bag, label and freeze. 
12. Tortillas

$(3 \times 1$ tortilla)

$58.9 \mathrm{~g} \quad 3$ frozen corn tortillas $\quad 50.0 \mathrm{~g} \quad \frac{1}{4}$ cup oil

Weigh and record weight of each ingredient. Weigh and record weight of each tortilla. Save one for raw.

Weigh, record weight and pour 2 tablespoons oil in iron skillet; weigh; record weight and pour 2 tablespoons oil in Corning dish. Record time. Heat oil over high heat until hot $\left(350^{\circ} \mathrm{F}.\right)$. Fry one tortilla in hot oil in iron skillet and one tortilla in hot oil in Corning dish until done (lightly browned on one side), turn and fry until done on the other side. Record time. Remove tortillas from cooking containers, drain tortillas momentarily on paper towel, and weigh and record weight of each tortilla.

Blend each of the three tortillas; take $\mathrm{pH}$ of each and record; and place each in a plastic bag, label and freeze. If necessary to blend and take $\mathrm{pH}$, add a small amount of deionized water (measure and record amount) to each tortilla.

\section{Medium White Sauce}

\section{( 3 X 1 cup)}
$85.2 \mathrm{~g} \quad 6$ tablespoons margarine
$43.2 \mathrm{~g} 6$ tablespoons flour
$703.5 \mathrm{~g} \quad 3$ cups milk
$9.9 \mathrm{~g} \quad 1^{1}{ }^{1}$ teaspoons salt

Weigh each ingredient and record weight. Divide each ingredient into thirds, weighing and recording weight of each third. Combine one third of each ingredient, weigh and record weight, and save for raw.

Record time. Melt one third of margarine in iron skillet over medium heat; melt one third of margarine in Corning dish over medium heat. Stir one third of flour into melted margarine in iron skillet; stir one third of flour into melted margarine in Corning dish. Stir one third of milk and one third of salt into mixture in iron skillet; stir one third of milk and one third of salt into mixture in Corning dish. Cook over medium heat, sitrring occasionally, until each mixture thickens. Record time and cooking time. Weigh each of the two sauces and record weight.

Blend each of the three thirds; take $\mathrm{pH}$ of each third and record; place each third in a plastic bag, label and freeze. 


\title{
14. Fried Egg
}

\section{$\left(\begin{array}{llll}3 & \times & 1 & \text { egg }\end{array}\right)$}

$25.0 \mathrm{~g} \quad 2$ tablespoons oil

$166.0 \mathrm{~g} \quad 3$ large eggs

Weigh and record weight of each egg. Save one egg for raw sample.

Weigh and record weight of oil. Weigh and record weight of one-half of the oil and use it to oil iron skillet; use the other half of oil to oil a Corning dish. Heat skillet and dish. Record time. Slip one egg gently into iron skillet; slip the other egg gently into Corning dish. Cook each of the two eggs over low heat 6 minutes, turning once to cook on each side. Record time and cooking time. Weigh each cooked egg and record weight.

Blend each of the three eggs; take $\mathrm{pH}$ of each egg and record; and place each in a plastic bag, label and freeze.

\section{Poached Egg}

\section{( 3 X 1 egg)}

\author{
$8.4 \mathrm{~g} 2$ teaspoons oil \\ $153.3 \mathrm{~g} 3$ large eggs \\ $474.0 \mathrm{ml} 2$ cups deionized water
}

Weigh and record weight of each egg. Save one egg for raw sample.

Weigh oil and record weight. Weigh and record weight of each half of the oil. Use one half of the oil to oil the iron skillet; use the other half to oil the Corning dish. Heat on medium heat. Measure and add enough water to make about $1 / 2$ " deep in iron skillet, recording the amount of water; add the same amount of water to the Corning dish and record. Bring water to boiling on high heat, reduce heat to simmer. Record time. From a saucer gently slip one egg into water in iron skillet; from a saucer gently slip one egg into water in Corning dish. Spoon water over each of the two eggs, cover and cook 5 minutes until thin film of white coagulates over yolk. Record time and cooking time. Weigh each of the two cooked eggs and record weight.

Blend each of the three eggs; take $\mathrm{pH}$ of each egg and record; place each egg in a plastic bag, label and freeze. 


\section{Pancakes}

\section{(3 X l large pancake)}

$\begin{array}{rlll}115.0 & \mathrm{~g} & 1 \text { cup flour } \\ 3.3 & \mathrm{~g} & \frac{1}{2} \text { teaspoon salt } \\ 8.3 \mathrm{~g} & 2 \text { teaspoon sugar } \\ 4.3 \mathrm{~g} & 1 \text { teaspoon baking powder }\end{array}$

$\begin{array}{rll}176.0 & \mathrm{~g} & 3 / 4 \text { cup milk } \\ 55.8 \mathrm{~g} & \mathrm{l} \text { egg } \\ 25.0 \mathrm{~g} & 2 \text { tablespoons oil } \\ 8.4 \mathrm{~g} & 2 \text { teaspoons oil }\end{array}$

Weigh and record weight of each ingredient. Sift dry ingredients together. Combine milk, egg and oil and stir with a fork until well mixed. Stir liquid ingredients into dry only to moisten dry. Divide into three equal portions, weighing and recording weight of each. Save one for raw sample.

Weigh and record weight of 1 teaspoon oil, pour in iron skillet, and heat over medium heat; weigh and record weight of 1 teaspoon oil, pour in Corning dish and heat over medium high heat. Record time. Pour one mixture onto the greased hot iron skillet; pour one mixture onto the greased hot Corning dish. Cook over medium heat until golden brown on one side, 2 minutes, turn and cook other side, 2 minutes. Record time and cooking time. Weigh each pancake and record weight.

Blend each of the three pancakes; take $\mathrm{pH}$ of each and record; and place each pancake sample in a plastic bag, label and freeze.

\section{Rice \\ (3 X 1 cup rice)}

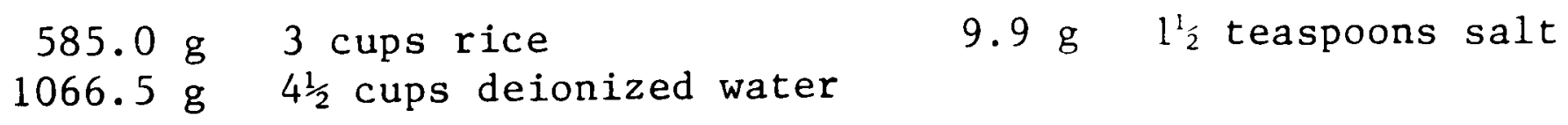

Weigh and record weight of each ingredient. Divide each ingredient into third, weighing and recording weight of each third of ingredient. Combine one third of each of the ingredients; weigh and record weight; and save for raw sample.

With one third of the ingredients: record time, stir rice into boiling salted water in iron skillet, cover and simmer until water is absorbed and rice grains are tender, dry and fluffy, about 20 minutes. With the other third of the ingredients: record time and cook as above except cook in Corning dish. Weigh each of the two cooked thirds and record weight.

Blend each of the three thirds; take $\mathrm{pH}$ of each and record; and place each third in a plastic bag, label and freeze. 


\section{Beef Vegetable Stew}

( $3 \times 2$ servings)

$\begin{array}{rll}551.1 & \mathrm{~g} & 1 \frac{1}{4} 1 \mathrm{~b} \text { stew beef } \mathrm{l}^{\prime \prime} \text { cubes } \\ 9.9 \mathrm{~g} & 1 \frac{1}{2} \text { teaspoons salt } \\ 1.8 \mathrm{~g} & \frac{1}{2} \text { teaspoon black pepper } \\ 43.2 & \mathrm{~g} & 6 \text { tablespoons flour } \\ 25.0 & \mathrm{~g} & 2 \text { tablespoons oil } \\ 711.0 \mathrm{~m} 1 & 3 \text { cups deionized water }\end{array}$
$323.3 \mathrm{~g} 3$ medium potatoes, peeled $185.8 \mathrm{~g} \quad 3$ medium carrots, peeled $325.0 \mathrm{~g} 3$ medium onions, peeled $232.6 \mathrm{~g} 3$ ribs celery $340.5 \mathrm{~g} \quad 1 \frac{1}{2}$ cups canned tomatoes with liquid

Weigh each ingredient and record weight. Divide each ingredient (except oil) into thirds, weighing and recording weight of each, placing one third of each ingredient on one of three waxed paper-lined trays labeled raw, iron and Corning.

Salt, pepper and flour each third of meat. Weigh one third of the seasoned, floured meat and record weight; save for raw sample.

Heat one half of the oil in iron skillet; heat one-half of the oil in Corning dish. Record time. Brown on medium high one third of meat on all sides in oil in iron skillet; brown one third of meat on all sides in oil in Corning dish. Add $118.5 \mathrm{ml}$ water to iron skillet; add $118.5 \mathrm{ml}$ water to Corning dish; add $118.5 \mathrm{ml}$ water to raw sample. Cover skillet and dish and simmer over low heat, 45 minutes, until almost tender; record time and cooking time.

Quarter vegetables. Add one third of vegetables and $118.5 \mathrm{ml}$ water to raw sample; add one third of vegetables and $118.5 \mathrm{ml}$ water to iron skillet; and add one third of vegetables and $118.5 \mathrm{ml}$ water to Corning dish. Record time; simmer vegetables, etc., in skillet and simmer vegetables, etc., in dish 20 minutes until tender; record time and cooking time.

Weigh and record cooked weight of each of the two stews. Weigh and record weight of the one third raw ingredients in the raw sample.

Blend each of the three thirds; take $\mathrm{pH}$ of each and record; and place each in a plastic bag, lable and freeze. 


\section{Fried Chicken}

( 3 X 3 hälves)

$\begin{array}{rlrl}2002.6 \mathrm{~g} & 1 \frac{1}{2} 3-1 \mathrm{~b} \text { fryers } & 28.8 \mathrm{~g} . & \frac{1}{2} \text { cup flour } \\ 6.6 \mathrm{~g} & 1 \text { teaspoon salt } & 400.0 \mathrm{~g} . & 2 \text { cups oil } \\ 1.4 \mathrm{~g} & \frac{1}{2} \text { teaspoon black pepper } & & \end{array}$

Weigh all ingredients and record weight. Split fryers into halves and divide all ingredients except oil into thirds by weight, weigh and record. Place one third of each ingredient (except no oil) on waxed paper lined tray for raw; place one third of each ingredient on waxed paper lined tray for iron; and place one third of each ingredient on waxed paper lined tray for Corning. (Put the left half of one fryer on iron tray and right half of the same fryer on the Corning tray; use the other half for the raw).

Cut each fryer half into four pieces (wing, drumstick, breast and thigh). Salt, pepper and flour the chicken. Weigh the seasoned and floured chicken pieces to be left raw, record weight, and place these chicken pieces in blender and cover to prevent drying out.

Heat $200.0 \mathrm{~g} \quad 1$ cup oil in iron skillet over high heat to $350^{\circ} \mathrm{F}$, hot but not smoking; heat $200.0 \mathrm{~g}$. 1 cup oil in Corning dish over high heat to $350^{\circ} \mathrm{F}$, hot but not smoking; record the temperature. Record the time. Cook the four pieces of cut fryer half in the hot oil, maintaining the $350^{\circ} \mathrm{F}$ temperature, over medium high heat until golden brown on one side; record time and cooking time; turn; and cook on other side until golden brown and chicken liquid is clear when drumstick and breast are cut with paring knife; record time and cooking time. Place each of the two chicken halves 1 minute on paper towel, turn pieces and let rest on paper towel on other side one minute. Weigh each cooked chicken half.

Cut meat from bones of the three chicken halves as completely as possible. Blend the seasoned meat for the raw recipe; blend the chicken which has been cooked in iron; blend the chicken which has been cooked in Corning. Take $\mathrm{pH}$ of each of the three chickens and record. Place each of the three chickens in plastic bag, label and freeze. 


\section{Liver with Onions}

\section{(3 X 2 servings)}
$657.0 \mathrm{~g} \quad 1^{1} \frac{1}{2} \mathrm{lb}$ beef 1 iver, sliced
$9.9 \mathrm{~g} \quad 1 \frac{1}{2}$ teaspoons salt
$0.9 \mathrm{~g} \frac{1}{4}$ teaspoon black pepper

$21.0 \mathrm{~g} 3$ tablespoons flour $264.3 \mathrm{~g} 3$ small onions, peeled $100.0 \mathrm{~g} \quad \frac{1}{2}$ cup oil

Weigh and record weight of each ingredient except liver. Remove membrane from slices of liver and snip out veins with shears. Weigh and record weight of liver. Peel and thinly slice the onions. Divide ingredients (except oil) into thirds; weigh and record each; and place one third of each ingredient on one of three waxed paper-lined trays. Divide oil into halves.

Salt, pepper, and flour each third of liver. Weigh and record the weight of one third of the seasoned, floured liver and one third of the sliced onions; place them in a blender and cover to prevent drying out. Heat oil in iron skillet over high heat; heat oil in Corning dish over high heat; record time. Brown one third liver quickly in hot oil in iron skillet, turn and brown other side; brown one third of liver quickly in hot oil in Corning dish, turn, and brown on other side; record time. Add onions, reduce heat, cover and cook over low heat 7 minutes until done; do not overcook. Record time and total cooking time.

Weigh each of the two cooked thirds of liver and onions and record. Blend the raw third of ingredients. Blend each cooked third. Take $\mathrm{pH}$ of each of the three thirds and record. Place each of the three thirds in plastic bags, label and freeze. 


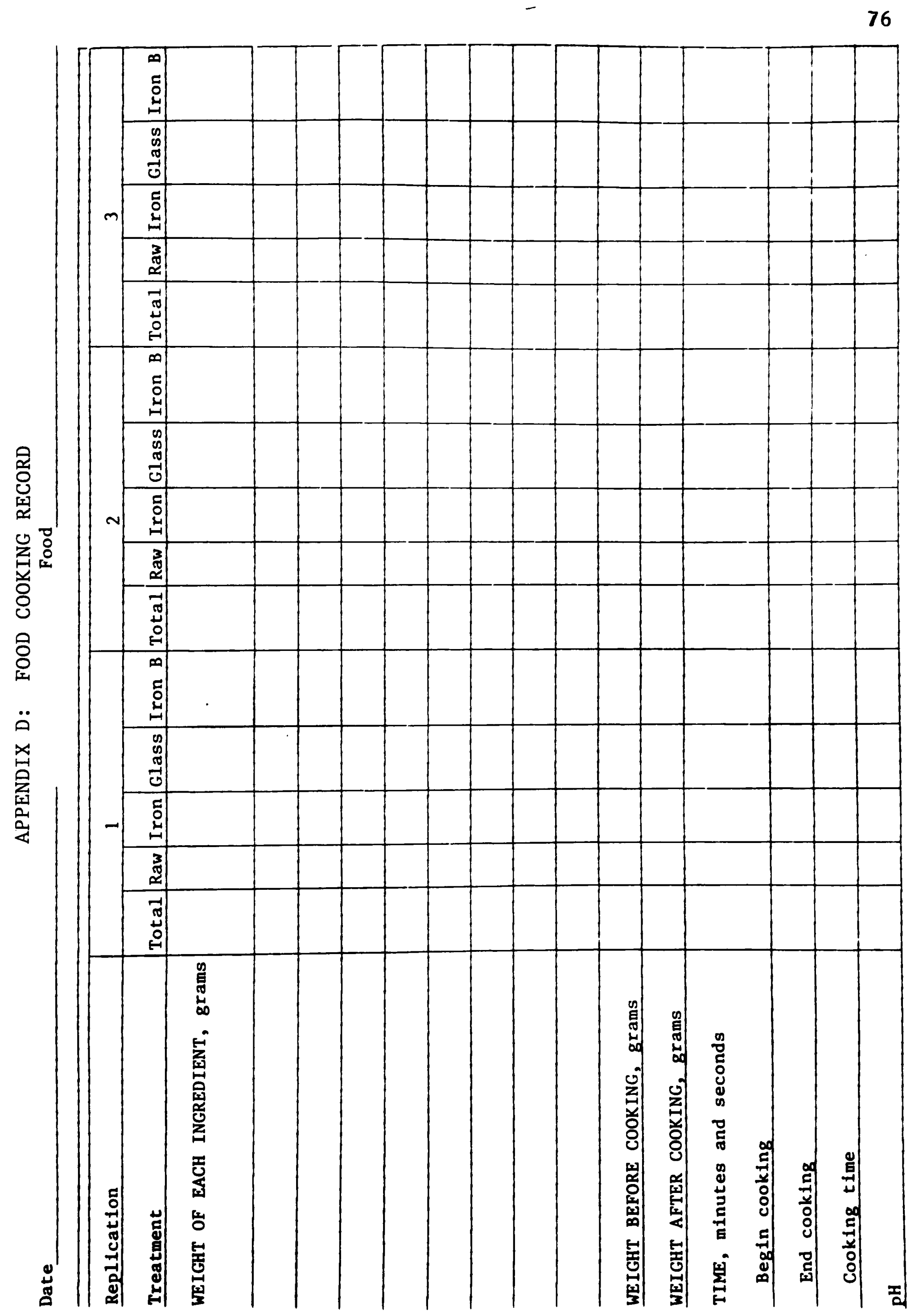


